\title{
Enhancement of Live Food Nutritional Status with Essential Nutrients for Improving Aquatic Animal Health: A Review
}

\author{
Nur Amalina Samat ${ }^{1,3}$, Fatimah Md Yusoff ${ }^{2,3}$, Nadiah W. Rasdi ${ }^{4,5}$ and Murni Karim ${ }^{2,3, *(1)}$ \\ 1 Laboratory of Aquatic Animal Health and Therapeutics, Institute of Biosciences, Universiti Putra \\ Malaysia (UPM), Serdang 43400, Selangor, Malaysia; amalinasamat@yahoo.com \\ 2 Laboratory of Sustainable Aquaculture, International Institute of Aquaculture and Aquatic Sciences, \\ Port Dickson 71050, Negeri Sembilan, Malaysia; fatimamy@upm.edu.my \\ 3 Department of Aquaculture, Faculty of Agriculture, Universiti Putra Malaysia (UPM), \\ Serdang 43400, Selangor, Malaysia \\ 4 School of Fisheries and Aquaculture Sciences, Universiti Malaysia Terengganu, \\ Kuala Terengganu 21300, Terengganu, Malaysia; nadiah.rasdi@umt.edu.my \\ 5 Institute of Tropical Biodiversity and Sustainable Development, Universiti Malaysia Terengganu, \\ Kuala Terengganu 21300, Terengganu, Malaysia \\ * Correspondence: murnimarlina@upm.edu.my; Tel.: +60-3-9769-4996
}

Received: 26 October 2020; Accepted: 25 November 2020; Published: 21 December 2020

Simple Summary: A highly nutritious quality diet that is readily accepted and digested is essential for better growth and development of aquaculture species. Most newly hatched fish and shrimp depend on live food as an important basic diet. Copepods are considered the nutritional benchmark diet for a wide range of marine fish larvae. However, Artemia and rotifers are often favored as starter feed, despite their inferior nutritional values in comparison to copepods. Therefore, Artemia, rotifers, and other live foods are commonly enriched with nutrients such as fatty acids, vitamins, minerals, and probiotics to imitate the copepod's level of essential nutrients to improve rearing success for fish and crustacean larvae.

\begin{abstract}
At the present time, no artificial larval diet is capable of entirely fulfilling the dietary requirements of several larval fish and crustacean species. Zooplankton live food is the basic foundation of fish larviculture, and successful rearing of fish larvae still heavily depends on an adequate supply of nutritious live food. Despite being important, the production protocols of copepods and cladocerans (Moina) are still underdeveloped in hatcheries. Rotifers and Artemia are the most commonly used live foods. However, these live foods are evidently lacking in crucial nutrient constituents. Hence, through nutrient enrichment, live food with the nutritional profile that meets the requirements of fish larvae can be produced. With the aim to maximize the effectiveness of production to optimize profitability, it is important to evaluate and improve culture techniques for the delivery of micro- and macro-nutrients as feed supplements to larvae in aquaculture systems. Bioencapsulation and enrichment are the evolving techniques in aquaculture that are commonly employed to enhance the nutritional quality of live food by integrating nutrients into them, which subsequently improves the growth, survival, and disease resistance of the consuming hosts. This review aims to highlight some of the approaches and methods used to improve the nutritional quality of live food by modifying their nutrient composition, which could have immense promise in the enhancement of aquatic animal health.
\end{abstract}

Keywords: live food; enrichment; nutrients; nutritional quality; aquatic health 


\section{Introduction}

Larvae of many aquatic species either have complete dependence on zooplankton live food as a basal diet, or they have significantly better performance when started on live food [1]. Live food is commonly regarded as "living capsules of nutrition", rich in proteins, vitamins, carbohydrates, minerals, amino acids, and fatty acids [2]. As a superior nutritional prey, some zooplankton contain high levels of digestive enzymes [3] and are capable of producing appetite-stimulating effects on larvae [4]. Live food organisms are able to swim freely in the water column, thereby being constantly accessible to finfish and crustacean larvae $[5,6]$. Their jerking movements are likely to stimulate larval feeding responses [7]. On the contrary, formulated feeds often accumulate on the water surface or some slowly sink to the bottom, whereby becoming less accessible to larvae [5]. Zooplankton such as rotifers and Artemia are by far the most commonly utilized live food in the cultivation of finfish and crustaceans [8].

Substitution of live food by formulated diets has been emphasized [9]. However, the sole application of a formulated diet may seem like a far-fetched idea due to low its digestibility and the deterioration of water quality [6,7]. Even though the use of live food in larval rearing has been reported to improve larval growth performance, survival, and disease resistance $[1,10,11]$, the cultivation and management of live food for aquatic production is costly and unpredictable [12]. Multiple studies have demonstrated the success of total live food replacement or reduction in aquaculture [9,13]. It is important to understand the nutritional requirements of fish larvae in order to facilitate the optimization of diets and feeding protocols, which may subsequently enhance larval quality $[7,14]$. Consequently, several studies have emphasized developing practical methods to improve the nutritional status of live food with essential nutrients [15-20].

By taking advantage of primitive feeding characteristics, the manipulation of the nutritional status of zooplankton is achievable by pre-feeding them through the so-called "bioencapsulation" or "enrichment" protocols. Through enrichment techniques, essential nutrients lacking in zooplankton, prophylactics, and therapeutics can be delivered to fish larvae via zooplankton live food. The application of enriched live food is reflected in enhanced growth, survival, stress tolerance, and microbial diversity for a variety of aquatic species [19,21-24]. A very important aspect of live food enrichment is its reproducibility and predictability, which are crucial in commercial hatcheries. Hence, it is necessary to constantly produce high-quality live food on a large scale [15]. However, producing enriched live food with consistent levels of the important nutrients can be complex. This review aimed to emphasize the significance of live food and the implementation of different enrichment techniques to incorporate nutrients such as minerals, vitamins, microalgae, lipids, and probiotics to enhance the nutritional status of the live food and to subsequently boost the health of the aquatic animals.

\section{Enrichment with Fatty Acids}

Highly unsaturated fatty acids (HUFA) with 20 or more carbon atoms are one of the major sources of metabolic energy during the embryonic and pre-feeding larval stages in fish. However, these energy sources rapidly declined during the endogenous feeding stage [25]. The n-3 series HUFA docosahexaenoic acid (DHA, 22:6n-3) and eicosapentaenoic acid (EPA, 20:5n-3), and the n-6 series HUFA arachidonic acid (ARA, 20:4n-6), play significant roles in fish larval development; thus, the deficiency of HUFA may impair fish growth, reproduction, and survival, causing pale or swollen liver, myocarditis, intestinal steatosis, lordosis, fin erosion, and shock syndrome [26]. HUFA are synthesized in very small concentrations from their precursors alpha-linolenic acid (ALA, 18:3n-3) and linoleic acid (LA, 18:2n-6) [27] due to the lack of delta- 5 and delta- 6 desaturases and elongases in marine fish larvae [28]. Therefore, HUFA must be incorporated through live foods such as copepods, rotifers and Artemia to meet the requirements for larval growth [27]. The requirements of HUFA in fish and crustaceans have been widely studied. The effects of dietary HUFA in the juveniles of golden pompano (Trachinotus ovatus) [29], yellowtail (Seriola dumerili) [30], Asian seabass (Lates calcarifer) [31], and Pacific white shrimp (Litopenaeus vannamei) [32] are among the most recently published studies. 
Enrichment of live food with commercial oil emulsion (Super Selco, DHA Selco, Selco S.presso) is a common practice [33-40]. Several studies have assessed the dietary fatty acid profiles of copepods and enriched Artemia [39,41,42]. The predominant fatty acids in copepods are DHA, EPA, and palmitic acid, while DHA, EPA, and oleic acid are the predominant fatty acids in Artemia enriched with Super Selco and DHA Selco [41]. Apart from the absolute amount of HUFA, the dietary DHA/EPA ratio is suggested to impact the normal growth and development of certain fish species $[43,44]$. The average DHA/EPA ratio for copepods ranged between 1.83 and 5.5 whereas the DHA/EPA ratio for Artemia enriched with DHA Selco ranged from 1.4 to 2.2 [41,42]. The DHA/EPA ratio of Artemia enriched with Super Selco at $600 \mathrm{mg} / \mathrm{L}$ for $16 \mathrm{~h}$ was reported at 0.2 [39], whilst enrichment at 200 and $300 \mathrm{mg} / \mathrm{L}$ for 24 and $20 \mathrm{~h}$, respectively, brought about 0.68 and 0.3 DHA/EPA ratio, respectively [38,41]. Altogether, Artemia enriched with DHA Selco recorded a higher DHA/EPA ratio than that of Super Selco. The instability of HUFA and the catabolism of these compounds by Artemia in addition to low DHA retention efficiency in Artemia during the first $24 \mathrm{~h}$ post enrichment might be the contributing factors to this variation $[38,41,45]$. Commercial emulsions are more stable and effective as the primary emulsions are mainly made from HUFA-rich fish oils and emulsified with egg yolk and seawater. However, these forms of enrichment formula are low in efficiency but are cheap alternatives in developing countries [7]. Higher DHA and EPA contents and DHA/EPA ratio were recorded in the freshwater cladoceran Moina micrura enriched with commercial emulsion (Maxepa MERCK, Delhi, India) in addition to gelatine, egg yolk, and Celin [19]. Modifications of dietary fatty acid compositions of rotifers and Artemia should be made in line with those of copepods.

Boosting of the nutritional status of rotifers [46,47], Artemia [48,49], copepods [50-57], and Moina [58] through algal enrichment techniques is a common practice to boost the quality of the otherwise nutrient-deficient feed. Microalgae is a rich source of HUFA and polyunsaturated fatty acids (PUFA) $[43,59,60]$. It is easier to control the essential fatty acid (EFA) composition of enrichment emulsions when microalgae-derived oil is used in comparison with purified fish oils [61]. Due to the high cost and difficulty in producing, concentrating, and storing live microalgae, the development of different forms of microalgae as a replacement to live microalgae has become a major focus of research [62]. A cheaper microalga paste has been used in aquaculture practice as an alternative to live microalgae [63]. Rotifers fed on microalgal pastes (Nannochloropsis oculata and Chlorella vulgaris) at equal quantities were rich in palmitic acid, linoleic acid, and EPA after $48 \mathrm{~h}$ of exposure to the microalgal diet. However, the DHA content was only recorded at $6 \mathrm{mg} / \mathrm{g}$ dry weight (DW). Nevertheless, the DHA content was enough to improve the growth, development, and stress resistance of fish larvae [64]. This study underlined the importance of enriching rotifers fed to larvae with multiple microalgal species over monospecific diets.

A previous study investigated the fatty acid composition of rotifers enriched with a mixture of DHA-enriched C. vulgaris (Super fresh Chlorella V12, SV, Chlorella Industry, Tokyo, Japan) and DHA emulsion (Bio Chromis, Chlorella Industry, Tokyo, Japan) for $12 \mathrm{~h}$ [43]. The DHA content in enriched rotifers increased from 0.1 to $15.4 \%$ and the DHA/EPA ratio was highest in the treatment. DHA was found to be dominant in rotifers enriched with DHA- and arachidonic acid (AA)-rich oils extracted from the dinoflagellate Crythecodinium sp. and the fungus Mortierella alpine, respectively, in addition to EPA-rich marine oil [65]. Rotifers have a better retention rate of EPA compared to DHA, regardless of the ratio in their enrichment [44]. Enrichment of rotifers can be achieved either through short-term enrichment (alteration of the lipid content of the rotifers just before larval feeding) and long-term enrichment (feeding of rotifers on a complete diet) [66,67]. Enriched DHA was stable in rotifers at $10{ }^{\circ} \mathrm{C}$ for at least $24 \mathrm{~h}$ post-enrichment under starving conditions, whereas a higher temperature of $20^{\circ} \mathrm{C}$ significantly decreased the DHA level during starvation [68]. Rotifers emptied their gut at a reduced rate as culture temperature decreased from $26{ }^{\circ} \mathrm{C}$ to $4{ }^{\circ} \mathrm{C}$ [69]. Moreover, microalgae are often added to the enrichment formula to promote "green water" to maintain the nutritional quality of zooplankton [64,70,71]. The larvae of rainbow trout (Oncorhynchus mykiss) [72], Russian sturgeon (Acipenser gueldenstaedtii) [73], Atlantic sturgeon (Acipenser oxyrinchus) [74], caspian kutum (Rutilus 
frisii kutum) [75], yellowtail flounder (Limanda ferruginea) [65], gilthead seabream (Sparus aurata) [28], and greater amberjack (S. dumerili) [24], whitefish (R. kutum) fry [76], and juvenile milkfish (Chanos chanos) [77] have been reared with live food enriched with essential fatty acids.

The high contents of EPA, DHA, and some digestive enzymes in copepods are among the important properties that make them a superior live food to Artemia and rotifers [6]. Therefore, it is recommended to enrich zooplankton in order to meet copepod HUFA levels. The enrichment emulsions are commonly prepared using commercial emulsions such as DHA Selco and Super Selco. To meet the copepod DHA/EPA ratio, it is recommended that Artemia and rotifers be enriched with DHA Selco. Even though studies on HUFA enrichment in Moina are fairly limited, a study has successfully enriched Moina with Maxepa. Additionally, HUFA enrichment can be performed using microalgae, either live or pastes. It is recommended that microalgae pastes be used as a cheaper alternative to live microalgae, and the application of multiple microalgal species over monospecific diets would be very beneficial. Moreover, a combination of commercial emulsions and microalgae in an enrichment mixture would be advantageous in terms of enhancing the DHA/EPA ratio.

\section{Enrichment with Vitamins}

\subsection{Vitamin C}

Vitamin C (VC) plays a vital role in the growth, immune response [78], hematology and histology [79], antioxidant and enzyme activities [80], reproduction [81], wound healing [82], and response to stressors [83] of fish and crustaceans. The addition of VC in aquaculture practices has been proven to enhance the growth performance, antioxidant defense system, and production of many aquatic animals including freshwater prawn (Macrobrachium malcolmsonii) [80] and kuruma shrimp (Marsupenaeus japonicus Bate) [84]. Enrichment of Artemia with of ascorbyl-6-palmitate for $24 \mathrm{~h}$ was observed to significantly reduce the mortality rate of seabream larvae [85]. However, it is necessary to note that a high dose of vitamin supplementation may cause lipid peroxidation in fish tissues under oxidative stress conditions [86]. The dietary requirement of VC may decrease with increased size [87]. Lack of VC can lead to structural deformities and internal hemorrhaging [88]. Some aquatic animals including the majority of crustacean and fish species are unable to synthesize VC because of the absence of the enzyme L-gluconolactone oxidase, which is essential for the last step of VC biosynthesis [89]. Hence, they depend on feed for a constant supply of VC.

Brown and Hohmann [90] reported a significant effect of the algal growth phase on the percentage of ascorbic acid in the culture of Isochrysis sp. However, the results need to be contextualized with the standard hatchery practice for algal production, the balance of other nutrients in the microalga, and the dietary requirements of the aquatic animal [90]. The enrichment of $A$. franciscana with the microalgae Isochrysis galbana for $72 \mathrm{~h}$ had a favorable impact on the amount of ascorbic acid in Artemia depending on the ascorbic acid content of I. galbana [45]. Moreover, the enrichment of rotifers with ascorbyl palmitate improved the assimilation of ascorbic acid when the percentage of ascorbyl palmitate incorporation in the enrichment media increased, thus suggesting that the ascorbic acid levels in Artemia nauplii can be manipulated via bioencapsulation of different ascorbyl palmitate concentrations [91]. The positive effects of feeding VC-enriched live food were reported on the larvae of milkfish (C. chanos) [92] and climbing perch (Anabas testudineus) [19], Senegalese sole (Solea senegalensis) [93], and Patagonian red octopus paralarvae (Enteroctopus megalocyathus) [94]. Generally, boosting of ascorbic acid content in zooplankton live food through the algal enrichment technique at a commercial hatchery yielded a lower ascorbic acid concentration than in the laboratory, probably due to differences in the culture conditions [91]. Different species and enrichment procedures resulted in different ascorbic acid levels in zooplankton [6], but the enrichment of microalgae with VC had been reported to increase the concentration of VC in Artemia [93], rotifers [95], and copepods [96]. However, it is crucial to have prior knowledge on the natural content of vitamins in microalgae before they are subjected to any enrichment procedure. There may be variations due to species and culture conditions with regards to light and 
nutrient conditions; protocols for harvesting, processing, and storage; extraction; and analysis [97]. The compositional data of vitamin contents in microalgae need to be compared to the dietary needs of the consuming aquatic animals. Unfortunately, the dietary requirements for larval or juvenile animals that feed on zooplankton are poorly understood [97]. Moreover, the concentrations of vitamins in the intermediary zooplankton and the transfer efficiency in the food chain are the area that requires further research $[97,98]$.

The pre-enrichment of microalgae with VC would be beneficial to a large group of filter-feeding zooplankton that utilize microalgae as a major source of food. Therefore, enrichment of zooplankton such as Artemia, rotifers, and copepods with microalgae to boost their VC levels is a practical approach. The levels of VC in zooplankton can be manipulated by enriching them with ascorbyl palmitate at different concentrations. However, when utilizing microalgae in an enrichment procedure, several factors including culture conditions, harvesting, processing, and storage protocols, as well as extraction and analysis must be taken into account, as these may greatly impact the VC levels in zooplankton live food.

\subsection{Vitamin $A$}

Vitamin A (VA) is a vital nutrient for fish as the compound cannot be synthesized de novo. Many VA or retinoid forms are available as dietary supplements including retinol (the alcohol form of VA), retinal (the aldehyde form), retinoic acid (the acid form), and retinyl acetate and retinyl palmitate (the ester form) [99]. VA hypervitaminosis can cause skeletal malformations in different vertebral regions, as well as cephalic malformations in jaw and fin complexes in other marine fishes, including the larvae of gilthead sea bream (S. aurata) [100], red sea bream (Chrysophrys major) [101], European sea bass (Dicentrarchus labrax) [102], Japanese flounder (Paralichthys olivaceus) [103,104], striped trumpeter (Latris lineata) and post larvae [99], and summer flounder (Paralichthys dendatus) [105]. The positive effect of dietary VA were reported on the juveniles of Nile tilapia (Oreochromis niloticus) [106] and spotted grouper (Epinephelus coioides) [107], on-growing gibel carp (Carassius auratus gibelio) [108], rainbow trout (O. mykiss) fry [109], and on Japanese flounder (P. olivaceus) larvae [110].

It was reported that VA deficiency in Artemia caused incomplete migration of the eye during Atlantic halibut (Hippoglossus hippoglossus L.) larvae metamorphosis [111]. Another study reported a higher concentration of VA in Atlantic halibut when fed with marine copepod than those fed with Artemia [112], probably because Artemia contains carotenoids in the form of cryptoxanthin or canthaxanthin, while the source of carotenoids in copepods is lutein and astaxanthin [61]. Thus, it is appropriate to enrich Artemia with copepod-type carotenoids. Furthermore, it was reported that the vitamin content in rotifers was below the levels found in copepods, but generally still within the range required by fish larvae [113]. Considering the limited amount of literature on fish larval nutrient requirements, the nutrient levels of copepod are considered as a target for the enrichment [114]. Moreover, VA was not detected in rotifers fed with basic diet containing Baker's yeast, suggesting a need for further enrichment with pure VA [113]. It is reported that the total VA accumulation in rotifers was independent to the dose $[17,114]$, but dependent to the added doses in the case of Artemia [115]. However, another study demonstrated otherwise [100]. Studies have demonstrated the possibility of zooplankton enrichment using liposomes [115] and commercial emulsion $[100,116]$, in which retinyl palmitate was the dominant form of the retinoids in the emulsions and in the enriched zooplankton. However, Monroig et al. [115] reported a noteworthy result of the poor efficiency of the commercial emulsion in Artemia, despite it containing retinyl palmitate, probably due to a partial degradation during the enrichment process influenced by different abiotic conditions. Moreover, the emulsion quality and properties; differences in the strains and batches of the zooplankton used; or the stages of development, metabolic capability, and filtration rates may contribute to the enrichment efficiency of the emulsions [17]. Therefore, the application of vesicles such as liposomes to bioencapsulate VA in live food is a promising approach. Liposomes as a retinyl palmitate carrier to zooplankton provide extra 
protection for VA from oxidation, and thus a higher amount of retinyl palmitate can be bioencapsulated in the zooplankton to be fed to aquatic animals [115].

Given the limited number of studies on fish larval nutrient requirements, the VA levels of copepods are considered as a target for enrichment. Artemia can be enriched with VA in the form of lutein and astaxanthin to meet the copepod VA levels. Even though the vitamin content in rotifers was below the levels found in copepods, it is still within the range required by fish larvae. Several studies reported that zooplankton such as Artemia can be enriched with liposomes and commercial emulsion. However, the partial degradation of VA during the enrichment process must be taken into account when employing commercial emulsions for zooplankton enrichment. Various studies on the applications of vitamin $\mathrm{C}$ and $\mathrm{A}$ in live food have been compiled in Table 1. 
Table 1. Enrichment of live food with vitamins.

\begin{tabular}{|c|c|c|c|c|c|}
\hline Vitamin & Live Feed & Biological Model & Method & Effects & References \\
\hline \multirow{7}{*}{ Vitamin C } & M. micrura & $\begin{array}{c}\text { Climbing perch (Anabes } \\
\text { testudineus) }\end{array}$ & Co-enrichment with HUFA for $24 \mathrm{~h}$ & Growth promoter & [19] \\
\hline & \multirow{3}{*}{ Artemia nauplii } & Senegalese sole (S. senegalensis) & $\begin{array}{l}\text { Co-enrichment with dietary Fe for } \\
24,29 \text {, and } 33 \mathrm{~h}\end{array}$ & Growth promoter & [93] \\
\hline & & $\begin{array}{l}\text { Patagonian red octopus ( } E . \\
\text { megalocyathus) }\end{array}$ & Co-enrichment with algae for $2 \mathrm{~h}$ & $\begin{array}{l}\text { Growth promoter and survival } \\
\text { improvement } \\
\text { (not significant) }\end{array}$ & [94] \\
\hline & & - & $\begin{array}{l}\text { Enrichment with unilamellar } \\
\text { liposomes composed of soybean } \\
\text { phosphatidylcholine and loaded } \\
\text { with sodium ascorbate }\end{array}$ & $\begin{array}{l}\text { Low vitamin } C \text { content in the } \\
\text { nauplii }\end{array}$ & [115] \\
\hline & $\begin{array}{c}\text { Moina, Daphnia, Cyclops, and } \\
\text { Diaptomus }\end{array}$ & Rohu (Labeo rohita) & $\begin{array}{l}\text { Enrichment with } 20 \% \text { ascorbyl } \\
\text { palmitate for } 12 \mathrm{~h}\end{array}$ & $\begin{array}{l}\text { Growth promoter and survival } \\
\text { improvement }\end{array}$ & [117] \\
\hline & $\begin{array}{l}\text { Artemia nauplii and rotifer } \\
\text { Brachionus plicatilis }\end{array}$ & Milkfish (C. chanos) & Co-enrichment with HUFA for $24 \mathrm{~h}$ & $\begin{array}{l}\text { Growth promoter, survival } \\
\text { improvement, and lower incidence } \\
\text { of opercular deformity }\end{array}$ & [92] \\
\hline & Rotifer Brachionus sp. & - & $\begin{array}{l}\text { Co-enrichment with thiamine, } \\
\text { vitamins } \mathrm{A} \text { and } \mathrm{E} \text {, and iodine }\end{array}$ & $\begin{array}{c}\text { Enrichment with } 4.6 \% \text { Stay C in the } \\
\text { diet could give copepod levels of } \\
\text { vitamin C }\end{array}$ & [114] \\
\hline \multirow{5}{*}{ Vitamin A } & Artemia nauplii & Striped trumpeter (L. lineata) & $\begin{array}{l}\text { Enrichment emulsions contain } \\
\text { retinyl palmitate together with } \\
\text { lipids, and vitamin E and } C(24 \mathrm{~h})\end{array}$ & $\begin{array}{l}\text { Growth and survival were not } \\
\text { significantly affected by increasing } \\
\text { dietary doses of retinyl palmitate }\end{array}$ & [118] \\
\hline & Artemia metanauplii & Senegalese sole (S. senegalensis) & $\begin{array}{l}\text { Addition of retinyl palmitate to a } \\
\text { commercial enrichment emulsion }\end{array}$ & Survival improvement & [119] \\
\hline & \multirow{2}{*}{ Rotifer B. plicatilis } & \multirow{2}{*}{ Striped trumpeter $($ L. lineata $)$} & \multirow{2}{*}{$\begin{array}{l}\text { Enrichment with retinyl palmitate } \\
\text { for } 2 \mathrm{~h}\end{array}$} & $\begin{array}{l}\text { Growth and survival were not } \\
\text { significantly affected by increasing } \\
\text { dietary doses of retinyl palmitate }\end{array}$ & \multirow{2}{*}{ [99] } \\
\hline & & & & $\begin{array}{l}\text { Retinyl palmitate enrichment in } \\
\text { rotifers did not affect the type or } \\
\text { severity of jaw malformations }\end{array}$ & \\
\hline & Rotifer & Atlantic cod (Gadus morhua) & $\begin{array}{l}\text { Co-enrichment with oil mixtures } \\
\text { for } 2 \mathrm{~h} \text { along with the addition of } \\
\text { fish meal, Selplex, and iodine }\end{array}$ & $\begin{array}{l}\text { Alteration of the skeletal } \\
\text { metabolism during larval } \\
\text { development }\end{array}$ & [120] \\
\hline
\end{tabular}




\section{Enrichment with Minerals}

\subsection{Selenium}

Selenium (Se) is a vital trace element for many aquatic animals; however, the line between requirement and toxicity is obscured [121]. Se acts as an antioxidant [122] and plays an important role in the regulation of the thyroid hormone metabolism and the endocrine system [123], cell signaling, growth, and survival [124]. Since Se cannot be produced naturally by living organisms, it has to be obtained from the diet [125]. Supplementation of Se to the basal diet is reported to enhance the growth of grouper (Epinephelus malabaricus) [126], Atlantic cod (G. morhua) larvae [127], and crucian carp (C. gibelio) [128]. It also plays a significant role in the detoxification of cadmium and green synthesized silver nanoparticle (Ag-NP) toxicity in abalone (Haliotis discus hannai) and Nile tilapia (O. niloticus), respectively $[129,130]$.

Enrichment of live food with selenium has been performed on rotifers [127] and Artemia [15] to meet the copepod Se levels. This element is transferred in the food chain to zooplankton and fish larvae [6]. It is reported that the concentration of Se in rotifers can be over 30 times lower than in copepods [113,127], which does not meet the mineral requirements of fish [131]. Therefore, it is necessary to establish an enrichment method to mass-produce rotifers with adequate amounts of the micronutrient. Ponce et al. [125] employed different rotifer enrichment strategies by using three forms of Se: selenite, selemethionine, and selenized yeast. The uptake of selenite increased linearly with exposure time while selemethionine was the dominant form in rotifers, confirming the ability of rotifers to metabolize and chemically transform selenite into selemethionine. Several works in the literature suggest that levels of Se between 1.4 and $3 \mathrm{mg} \mathrm{Se} / \mathrm{kg}$ DW in rotifers meet the requirements of fish larvae $[127,132,133]$, and the copepod Se levels are reported to range from 3 to $5 \mathrm{mg} \mathrm{Se} / \mathrm{kg}$ DW [113]. Therefore, it is recommended that rotifers be enriched with selenite, selemethionine, and selenized yeast at $2,0.2$, and $0.2 \mathrm{mg}$ of Se per $10^{6}$ rotifers for $12,1.5$, and $2 \mathrm{~h}$, respectively, in order to achieve copepod Se levels of $3 \mathrm{mg}$ Se $/ \mathrm{kg}$ DW and the high accumulation of selemethionine in rotifers [125]. However, Penglase et al. [134] and Ribeiro et al. [135] demonstrated that 2.1 and $3 \mathrm{mg}$ of selenized yeast per $10^{6}$ rotifers, respectively, in $3 \mathrm{~h}$ enrichments were needed to achieve the copepod Se levels. In the case of Artemia, $3 \mathrm{mg}$ of selenized yeast per million individuals and $12 \mathrm{mg} / \mathrm{L}$ in 3 and $4 \mathrm{~h}$ enrichments, respectively, were needed to achieve the copepod Se levels [15,133]. These contrasts were probably due to the presence of other ingredients such as lyophilized algae, fish oil, and other commercial enrichment formulations. Thus, it can be concluded that the estimation of the Se enrichment duration varies substantially according to the Se sources. Selenized yeast, an organic source of Se, can be produced by exposing yeast to sodium selenite [136], resulting in the accumulation of selenomethionine. Se from organic sources is regarded to be more bioavailable for fish than those from inorganic Se [125], and the enrichment of Se via selenized yeast resulted in high retention of Se in enriched rotifers for an extended period of time [134]. Therefore, the enrichment of rotifers with selenized yeast can be used as an excellent Se delivery method to confer health benefits to fish larvae.

Kim et al. [132] studied the effects of enriching microalgae $C$. vulgaris with Se (sodium selenite at $3.3 \mathrm{mg} \mathrm{Se} / \mathrm{kg} \mathrm{DW}$ ) on sexual and asexual reproduction of rotifers. Improved population growth, fertilization rate, and resting egg formation were observed due to the antioxidant abilities of glutathione peroxidase (GPx). GPx, a selenoprotein, is a compound that maintains the mechanical stability of spermatozoa [137], thus influencing the rates of fertilization. The study presented a method to produce a high-density mass culture of rotifers. Another approach involves the use of Se in the form of selenium nanoparticles (SeNPs). SeNPs has similar efficiency as organic Se forms that exhibit lower toxicity [138,139] and possesses antibacterial properties [140]. It was reported that the enrichment of Artemia with $5 \mathrm{mg} / \mathrm{L} \mathrm{SeNP}$ solution for $24 \mathrm{~h}$ was needed to achieve the optimal Se content $(4 \mathrm{mg} / \mathrm{kg}$ ) (dry matter) of the feed for fish larvae. The enrichment solution contained nano-elemental Se, produced on the basis of a new ascorbic acid reduction method. Furthermore, SeNP had been previously biosynthesized by various microorganisms including Pseudomonas alcaliphila [141], Bacillus sp. [142], 
Zooglea ramigera [143], and Enterococcus faecalis [140]. Artemia salina fed with SeNP-enriched Yarrowia lipolytica biomass showed improved growth, survival, and disease resistance against Vibrio harveyi [144]. The SeNP used in the study was synthesized from the incubation of Y. lipolytica cells with $4 \mathrm{mM}$ sodium selenite for $48 \mathrm{~h}$. However, it is necessary to note that the toxicity of SeNP is different from those of other Se species and is poorly understood. Indeed, a study suggested that exposure to SeNP caused malformations in Japanese medaka (Oryzias latipes) offspring [145]. It is known that Se supplementation through zooplankton enrichment can enhance fish growth [146], survival [121,127], and thyroid hormone status. Therefore, the use of Se from organic sources and SeNP of lower toxicity would be highly beneficial to fish larvae.

In conclusion, the concentration of Se in rotifers and Artemia is much lower than in copepods. Therefore, it is common to enrich live food with Se to meet the copepod Se levels. Enrichment of zooplankton with Se can be performed using different forms of Se such as selenite, selemethionine, selenized yeast, and SeNPs. It is recommended that rotifers be enriched with selenized yeast at $0.2 \mathrm{mg}$ of Se per $10^{6}$ rotifers for $2 \mathrm{~h}$ to achieve the copepod Se levels. Meanwhile, it is recommended that Artemia be enriched with $3 \mathrm{mg}$ of selenized yeast per million individuals for $3 \mathrm{~h}$ to achieve the copepod Se levels. Moreover, the enrichment of Artemia with $5 \mathrm{mg} / \mathrm{L} \mathrm{SeNP}$ solutions for $24 \mathrm{~h}$ is recommended to achieve the optimal Se content. However, the presence of other ingredients in commercial enrichment formulations and enrichment duration may influence the final concentration of Se in zooplankton.

\subsection{Iodine}

Iodine (I) is a crucial component of thyroid hormone, responsible for fish metamorphosis [147]. Since marine fish larvae feed naturally on copepods, their nutrient levels are commonly used as a reference to indicate larval dietary requirements $[6,42,113]$. Copepod I levels are reported to range from 50 to $350 \mathrm{mg} / \mathrm{kg}$ DW, 10-fold higher on average than that of rotifers [113] and significantly higher than that of Artemia, which only range from 1.1 to $4.6 \mathrm{mg} / \mathrm{kg}$ DW [148]. The superior I content in copepods compared to Artemia suggests that assimilation of I by the consuming fish larvae could be the cause for a significant increase in the synthesis of thyroid hormone and in the whole body I level [148]. Enrichment with $400 \mathrm{mg} / \mathrm{L}$ sodium iodide for $1.5 \mathrm{~h}$ can increase the concentration of I in rotifers to $112 \mathrm{mg} / \mathrm{kg}$ DW, but the I concentration in fish larvae may not be affected by the I enrichment of the rotifers [127]. In contrast, Ribeiro et al. [18] reported 47.86 and $64.2 \mathrm{mg} / \mathrm{kg}$ wet weight (WW) I in rotifers and Artemia, respectively, after $3 \mathrm{~h}$ enrichment with sodium iodide (at either $100 \mathrm{or} 200 \mathrm{mg} / \mathrm{L}$, depending on the density of the zooplankton). Consequently, larval whole-body I content showed a significant increase when fed with the enriched zooplankton. In multiple studies, Lipiodol Ultra Fluid, an ethiodized oil, was used as the I source in the enrichment diet [114,147]. It is advisable that rotifers be enriched with Lipiodol from 52 to $392 \mathrm{mg} / \mathrm{kg}$ DW to acquire copepod I level [114]. With regard to Artemia, enrichment with $6.25 \mathrm{mg} / \mathrm{kg}$ WW Lipiodol for $24 \mathrm{~h}$ resulted in an I concentration of $318 \mathrm{mg} / \mathrm{kg}$ DW, which was within the range found in copepods [147]. Furthermore, the enrichment with Lipiodol resulted in high retention of I in enriched Artemia for up to $6 \mathrm{~h}$, and the whole body I concentration in the consuming fish larvae was improved when fed on the enriched Artemia. A study demonstrated the enrichment of rotifers for $3 \mathrm{~h}$ with different I sources: thymol iodide, 3,5-diiodosalicylic acid, chelated iodine, kelp, and sodium iodide [149]. Chelated iodine was found to be a poor source of I for rotifer enrichment and failed to reach minimum copepod I levels. The level of I in fish larvae varies depending on the species of zooplankton, the form of I, and the enrichment method. Differences due to different rearing conditions between these studies should be considered. Moreover, whether fish larvae can absorb and regulate I in the form of iodide from seawater is still unknown [147]. Iodine from seawater may be sufficient in adult fishes but is probably still not enough to achieve adequate exogenous thyroxine (T4) tissue concentration [148]. It is known that the supplementation of I through zooplankton enrichment can improve fish thyroid hormone level [148] and survival [127], besides preventing goiter [18].

In conclusion, as the concentrations of I in Artemia and rotifers are reported to be much lower than the copepod I levels, it is recommended that Artemia and rotifers be further enriched with 
sodium iodide. It is recommended that Artemia and rotifers be enriched with 100 and $200 \mathrm{mg} / \mathrm{L}$ sodium iodide, respectively, for $3 \mathrm{~h}$ to meet the copepod I levels. Consequently, an improved larval whole-body I content was reported when Artemia and rotifers were fed with the enriched zooplankton. Furthermore, different sources of I such as Lipiodol, thymol iodide, 3,5-diiodosalicylic acid, and kelp can be good substitutes to sodium iodide for zooplankton enrichment. However, factors including the species of zooplankton, the form of I, the enrichment method, and the rearing conditions must be considered when preparing the enrichment emulsions.

\subsection{Other Trace Metals}

The level of other minerals in rotifers are lower than in copepods, with manganese (Mn), copper $(\mathrm{Cu})$, and zinc $(\mathrm{Zn})$ by two-, three-, and five-fold respectively on average [113]. In general, fish larvae fed with rotifers are likely to have limited $\mathrm{Zn}$ and Se concentrations, while $\mathrm{Mn}, \mathrm{Fe}, \mathrm{Cu}$, cobalt (Co), and iron (Fe) generally meet the fish dietary requirements [150]. Shortage of Mn, Fe, and Co may occur in fish at the late larval stage when fed on non-enriched Artemia [150]. Thus, co-feeding Artemia with rotifers or enrichment is highly recommended in larviculture practices. Enrichment of rotifers with an organically bound mineral mix (I chelate, $\mathrm{Mn}$ proteinate, $\mathrm{Cu}$ proteinate, $\mathrm{Zn}$ proteinate, and selenized yeast) for $3 \mathrm{~h}$ can uplift rotifers to copepod levels of $\mathrm{Mn}, \mathrm{Cu}, \mathrm{Zn}$, and Se by replacing 6\% of the commercial rotifer enrichment diet [151]. Enrichment of rotifers with minerals bound to an ingestible particle was more effective than minerals in soluble forms [134]. Furthermore, the retentions of Mn, Cu, $\mathrm{Zn}$, and Se in rotifers were high after $18 \mathrm{~h}$ storage in clear water [151]. High rotifer mineral retention is an important aspect of the commercial hatchery management to ensure the intended mineral quantity is consumed by fish larvae. Moreover, enrichment of microalgae with minerals has been proposed due to the inability of zooplankton to directly absorb and retain minerals from the culture media $[20,93,152]$. Feeding of rotifers with Chlorella is a more effective approach to deliver $\mathrm{Zn}$ and Cu due to the ability of Chlorella to absorb and pre-accumulate waterborne $\mathrm{Zn}$ and $\mathrm{Cu}[20,152]$. The rotifer $\mathrm{Zn}$ and $\mathrm{Cu}$ contents were recorded at 373.2 and $50.5 \mathrm{mg} / \mathrm{kg} \mathrm{DW}$, respectively, when fed with enriched microalgae at $0.8 \mathrm{mg}$ $\mathrm{Zn} / \mathrm{g}$ and $0.1 \mathrm{mg} \mathrm{Cu} / \mathrm{g}$ Chlorella, respectively, for $24 \mathrm{~h}$ [20,152]. The Zn content was within the range found in copepods (340 to $570 \mathrm{mg} / \mathrm{kg} \mathrm{DW}$ ), whereas the $\mathrm{Cu}$ content recorded in enriched rotifers was slightly higher than the copepod Cu levels (12 to $38 \mathrm{mg} / \mathrm{kg} \mathrm{DW}$ ) [113]. The constituents of Chlorella cell wall allow for the assemblage of ligands with different functional groups capable of binding different heavy metals [20]. The enhancement of the Fe content of Artemia through microalgae enrichment has been reported. Enrichment of microalgae Tisochrysis lutea with Fe $(10 \mu \mathrm{g} / \mathrm{mL})$ displayed a high content of Fe at $850 \mathrm{mg} / \mathrm{kg}$ DW, which was higher than the copepod Fe levels (85 to $371 \mathrm{mg} / \mathrm{kg}$ DW) [93]. It is important to note that the enrichment of zooplankton with one mineral may disturb the composition of the other minerals [20]. The literature suggest that zooplankton can be enriched with minerals by means of food ingestion rather than by immersion in enrichment media to promote better growth and physiological status of fish larvae in hatcheries. The positive effects of mineral enrichment to copepod levels in rotifers and Artemia were demonstrated in the larvae of red sea bream (Pagrus major) [153], Senegalese sole (S. senegalensis) [93], and Chinese Mitten crab (Eriocheir sinensis) [20,154].

In conclusion, fish larvae fed with non-enriched rotifers were likely to have limited $\mathrm{Zn}$ and Se concentrations. Fish at the late larval stage fed with non-enriched Artemia may experience a shortage of $\mathrm{Mn}, \mathrm{Fe}$, and $\mathrm{Co}$. As the levels of other minerals including $\mathrm{Mn}, \mathrm{Cu}$, and $\mathrm{Zn}$ in rotifers and Artemia are much lower than in copepods, it is highly recommended that the zooplankton be enriched with minerals prior to larval feeding. Generally, the feeding of rotifers and Artemia with microalgae is regarded to be a more effective approach than the immersion method to deliver minerals to the zooplankton and fish larvae. Various studies on the applications of minerals in live food are compiled in Table 2. 
Table 2. Enrichment of live food with minerals.

\begin{tabular}{|c|c|c|c|c|c|}
\hline Mineral & Live Feed & Biological Model & Method & Effects & References \\
\hline \multirow{11}{*}{ Selenium } & Artemia nauplii & - & $\begin{array}{l}\text { Enrichment with sodium selenite and } \\
\text { selenoyeast at } 24 \mu \mathrm{g} / \mathrm{L} \text { for } 4 \mathrm{~h}\end{array}$ & $\begin{array}{l}\text { Enrichment with selenoyeast increased } \\
\text { the levels of Se in the nauplii }\end{array}$ & [15] \\
\hline & Artemia sp. & Red drum (Sciaenops ocellatus) & Enrichment with nano-selenium & $\begin{array}{l}\text { Promotion of growth and improved } \\
\text { survival }\end{array}$ & [121] \\
\hline & \multirow{4}{*}{ Rotifer B. plicatilis } & - & $\begin{array}{l}\text { Enrichment with selenite }(2 \mathrm{mg}) \text {, } \\
\text { selenomethionine }(0.2 \mathrm{mg}) \text {, and selenized } \\
\text { yeast }(0.2 \mathrm{mg}) \text { for } 12,3 \text {, and } 6 \mathrm{~h} \text {, } \\
\text { respectively }\end{array}$ & $\begin{array}{l}\text { Rotifers with Se levels similar to those } \\
\text { in copepods can be achieved }\end{array}$ & [125] \\
\hline & & Atlantic cod (G. morhua) & $\begin{array}{l}\text { Co-enrichment with sodium selenite (7 } \\
\mathrm{mg} / \mathrm{L}) \text { and sodium iodide }(400 \mathrm{mg} / \mathrm{L}) \text { for } \\
1.5 \mathrm{~h}\end{array}$ & Improved survival & [127] \\
\hline & & - & $\begin{array}{c}\text { Enrichment with Se-fortified C. vulgaris } \\
\text { (containing } 3.3 \mu \mathrm{g} \mathrm{Se} / \mathrm{g} \text { DW) at } 2.5 \times 10^{6} \\
\text { cells } / \mathrm{mL}\end{array}$ & $\begin{array}{l}\text { Higher population growth, rates of } \\
\text { fertilization, and absolute resting egg } \\
\text { production of rotifers }\end{array}$ & [132] \\
\hline & & - & $\begin{array}{c}\text { Enrichment with selenized yeast at } 0.01 \\
0.02,0.025,0.04, \text { and } 0.08 \text { g per million } \\
\text { rotifers for } 3 \mathrm{~h}\end{array}$ & $\begin{array}{l}\text { The Se levels obtained were higher } \\
\text { than copepods Se levels }\end{array}$ & [135] \\
\hline & $\begin{array}{l}\text { Artemia nauplii and } \\
\text { rotifer B. plicatilis }\end{array}$ & Senegalese sole (S. senegalensis) & $\begin{array}{l}\text { Enrichment with } 0.003 \mathrm{~g} \text { of selenized yeast } \\
\text { per million individuals and DHA Selco for } \\
\qquad 3 \mathrm{~h}\end{array}$ & $\begin{array}{l}\text { The activity of glutathione peroxidase } \\
\text { and the production of thyroid hormone } \\
\text { were higher }\end{array}$ & [133] \\
\hline & Rotifer Brachionus spp. & - & $\begin{array}{l}\text { Enrichment with selenized yeast at } 1.7 \mathrm{mg} \\
\text { for } 6 \text { days and } 3.2 \mathrm{mg} \text { for } 3 \mathrm{~h}\end{array}$ & $\begin{array}{l}\text { A high retention rate of Se for up to } 10 \\
\text { h storage in clear water at cold }\left(10^{\circ} \mathrm{C}\right) \\
\text { or warm }\left(20^{\circ} \mathrm{C}\right) \text { temperatures }\end{array}$ & [134] \\
\hline & A. salina & - & $\begin{array}{l}\text { SeNP enriched biomass of } Y \text {. lipolytica at } \\
10^{9} \text { cells/mL was added every } 24 \mathrm{~h}\end{array}$ & $\begin{array}{l}\text { Promotion of growth, improvement in } \\
\text { survival, and enhancement in disease } \\
\text { resistance }\end{array}$ & [144] \\
\hline & $\begin{array}{l}\text { Rotifer Brachionus } \\
\text { rotundiformis }\end{array}$ & Red seabream (P. major) & $\begin{array}{l}\text { Enrichment with Se-fortified C. vulgaris } \\
\left(3.2 \mu \mathrm{g} \mathrm{Se} / \mathrm{g} \text { DW) at } 5 \times 10^{5} \text { cells } / \mathrm{mL}\right.\end{array}$ & $\begin{array}{c}\text { Promotion of growth and higher Se } \\
\text { concentrations of rotifers and fish } \\
\text { larvae }\end{array}$ & [146] \\
\hline & $\begin{array}{l}\text { Rotifer B. plicatilis and } \\
\text { Artemia }\end{array}$ & Senegalese sole (S. senegalensis) & $\begin{array}{l}\text { Enrichment with } 780 \mathrm{mg} \text { sodium iodide } \\
\text { per } 1 \mathrm{~g} \text { emulsions: Rich Advance (for } \\
\text { rotifers) or Super Selco (for Artemia) for } 3 \mathrm{~h}\end{array}$ & $\begin{array}{c}\text { Promotion of growth; moreover, the } \\
\text { whole body I concentration of larvae } \\
\text { fed the I-enriched live food was higher } \\
\text { compared to control larvae }\end{array}$ & [18] \\
\hline
\end{tabular}

Iodine 
Table 2. Cont.

\begin{tabular}{|c|c|c|c|c|c|}
\hline Mineral & Live Feed & Biological Model & Method & Effects & References \\
\hline & $\begin{array}{l}\text { Rotifer Brachionus } \\
\text { "Cayman" }\end{array}$ & - & $\begin{array}{l}\text { Rotifers were fed three meals daily } \\
\text { (containing Lipiodol at either 100, 200, or } \\
300 \mathrm{mg} / \mathrm{kg} \text { DW feed) for } 4 \text { days }\end{array}$ & $\begin{array}{l}52 \mathrm{mg} / \mathrm{kg} \text { dietary iodide would be } \\
\text { needed to obtain the lower range of } \\
\text { copepod levels of iodine }\end{array}$ & [114] \\
\hline & Rotifer B. plicatilis & - & $\begin{array}{l}\text { Enrichment with } 200 \mathrm{mg} \text { sodium iodide } \\
\text { per million rotifers and mixed with DC } \\
\text { DHA Selco for } 3 \text { and } 6 \mathrm{~h}\end{array}$ & $\begin{array}{l}\text { The I levels in the enriched rotifers } \\
\text { were significantly higher than those of } \\
\text { the control rotifers }\end{array}$ & [135] \\
\hline & Artemia nauplii & $\begin{array}{l}\text { Atlantic halibut }(H . \\
\text { hippoglossus) }\end{array}$ & $\begin{array}{l}\text { Enrichment with Lipiodol Ultra Fluid at } \\
\qquad 0.2 \mathrm{~g} / \mathrm{L} \text { for } 24 \mathrm{~h}\end{array}$ & $\begin{array}{l}\text { Enhancement in the levels of I in fish } \\
\text { larvae }\end{array}$ & [147] \\
\hline & $\begin{array}{l}\text { Rotifer Brachionus } \\
\text { "Cayman" }\end{array}$ & - & $\begin{array}{c}\text { Rotifers were enriched with a diet } \\
\text { containing either thymol iodide, } \\
\text { 3,5-diiodosalicylic acid (both at } 9.7 \mathrm{~g} / \mathrm{kg} \\
\text { rotifer DW), or sodium iodide (at } 0.3 \mathrm{~g} / \mathrm{L} \text { ) } \\
\text { for } 3 \mathrm{~h}\end{array}$ & $\begin{array}{c}\text { The levels of I in rotifers met copepods } \\
\text { I levels }\end{array}$ & [149] \\
\hline \multirow{4}{*}{$\begin{array}{l}\text { Other trace } \\
\text { metals }\end{array}$} & Rotifer Brachionus sp. & - & $\begin{array}{c}\text { Enrichment with yeast and oil, yeast and } \\
\text { Algamac 2000, yeast and Chlorella, and } \\
\text { Culture Selco }\end{array}$ & $\begin{array}{c}\text { The } \mathrm{I}, \mathrm{Mn}, \mathrm{Cu}, \mathrm{Zn}, \mathrm{Se} \text {, and } \mathrm{Fe} \\
\text { concentrations in rotifers were lower } \\
\text { than the concentrations measured in } \\
\text { copepods }\end{array}$ & [113] \\
\hline & Rotifer B. plicatilis & - & $\begin{array}{l}\text { Pre-accumulation of } 1 \mathrm{~mL} \text { zinc sulphate } \\
\text { solution in } 10 \mathrm{~g} \text { Chlorella for } 12 \mathrm{~h} \text {. Followed } \\
\text { by the incubation of rotifers with } \\
\text { Zn-enriched Chlorella at } 1.8 \times 10^{6} \text { cells/mL } \\
\text { for } 24 \mathrm{~h}\end{array}$ & $\begin{array}{l}\text { The } \mathrm{Zn} \text { content of rotifers fed } \\
\text { zinc-enriched Chlorella was } \\
\text { significantly higher than that of rotifers } \\
\text { fed unenriched Chlorella }\end{array}$ & [152] \\
\hline & \multirow{2}{*}{ Artemia nauplii } & Red seabream ( $P$. major $)$ & $\begin{array}{l}\text { Prior enrichment of marine } \omega \text { A with } 0.1 \\
\mathrm{mg} \mathrm{Zn} / \mathrm{mL} \text { or } 0.24 \mathrm{mg} \mathrm{Mn} / \mathrm{mL} \text { for } 2 \mathrm{~h} \\
\text { before incubated with Artemia for } 32 \mathrm{~h}\end{array}$ & $\begin{array}{l}\text { Growth and normal skeletal } \\
\text { development were promoted }\end{array}$ & [153] \\
\hline & & Chinese mitten crab (E. sinensis) & $\begin{array}{l}\text { Prior enrichment of marine } \omega \mathrm{A} \text { with } 0.1 \\
0.2, \text { or } 0.4 \mathrm{mg} \mathrm{Cu} / \mathrm{mL} \text { for } 3 \mathrm{~h} \text { before } \\
\text { incubated with Artemia for } 24 \mathrm{~h}\end{array}$ & $\begin{array}{l}\text { Promotion of growth, superoxide } \\
\text { dismutase, and catalase activity } \\
\text { enhancement, and improvement of } \\
\text { salinity stress tolerance }\end{array}$ & [154] \\
\hline
\end{tabular}




\section{Enrichment with Probiotics}

The expansion of aquacultural activities together with environmental issues including climate change often contribute to conditions favoring disease outbreaks [155]. Disease is now a primary constraint to the culture of many aquatic species and therefore may put countries that rely heavily on fisheries for their livelihood in economic hardship or missed opportunities for development [156]. The conventional use of antibiotics for controlling bacterial infections is controversial and no longer effective in treating bacterial diseases in some cases [157-160]. Dietary administration of feed supplements such as probiotics to control or treat diseases has received increasing attention in recent years [161]. The term probiotics originated from the Greek words "pro bios" which mean "for life" [162]. In 1989, Fuller [163] revised the definition of probiotics to "a live microbial feed supplement which beneficially affects the host animal by improving its intestinal microbial balance". Probiotics were then redefined as "live microorganisms which when administered in adequate amounts confer health benefits on the host" [164].

At the early development stage, artificial dominance of a specific cluster of bacteria can be stimulated in the host by the addition of a probiotic strain directly to the rearing water or the cultivation medium of the live food $[165,166]$. Administration of probiotics to the gut of the target host through probiotics enrichment in a bioencapsulation method of zooplankton live food is an interesting approach in some cases [167]. Bioencapsulation of live food with probiotics to enhance zooplankton growth, population density, and reproductive capacities has been reported [168-174].

Combined administration of two or more probiotic strains is considered to be more effective than single-strain administration in most cases [161]. Artemia accumulated the highest concentration of lactic acid bacteria (LAB) $\left(5.22 \times 10^{3}\right.$ (colony-forming unit $\left.(\mathrm{CFU}) / \mathrm{mL}\right)$ when enriched with a mixture of three indigenous LAB (Lactobacillus plantarum, Lactobacillus salivarus, and Lactobacillus rhamnosus) at

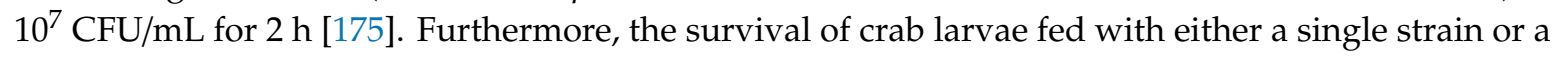
mixture of three LAB isolates via bioencapsulation was not significantly different between treatments but still higher than the control treatment. Thus, feeding of crab larvae with LAB-encapsulated zooplankton along with the direct addition of LAB to the rearing system may yield better results [176]. Generally, the administration of indigenous probiotic strains that include those from the normal dominant gastrointestinal microbiota of the host or any of its development phases is likely to yield dominant colonization [177]. Gatesoupe [178] reported the ability of three LAB strains to improve the production rate of rotifers. The mean concentration $(150$ rotifers $/ \mathrm{mL})$ and the production rate (34 rotifers/mL) were highest when enriched with $8 \mathrm{mg} / \mathrm{L} \mathrm{DW} \mathrm{L.} \mathrm{plantarum} \mathrm{alone} \mathrm{for} 15 \mathrm{~min}$ every $6 \mathrm{~h}$ daily from day 6 until day 15 . The spray drying method of whey culture medium with $10^{6} \mathrm{CFU} / \mathrm{g}$ L. plantarum was applied. The whey culture medium is often used as a carrier material for probiotic microencapsulation and generally contains lactose and soluble proteins [179]. However, a subsequent study found that enrichment of rotifers with two LAB strains between $10^{7}$ and $2 \times 10^{7} \mathrm{CFU} / \mathrm{mL}$ once a day was enough to protect the consuming fish larvae from Vibrio sp. infection [180]. Despite the addition of probiotic mix (Mycobacterium, Ruegeria, Pseudoalteromonas, Vibrio) at $5 \times 10^{6} \mathrm{CFU} / \mathrm{mL}$ directly to the rearing water together with the administration of rotifers and Artemia enriched with the equal mixture of the four probiotic strains at $4 \times 10^{8} \mathrm{CFU} / \mathrm{mL}$ for $30 \mathrm{~min}$, all strains were only transiently found in the larval microbiota [166]. The ability of the probiotic strains to grow in the planktonic state, or to establish biofilms in the tank walls and selective grazing by the zooplankton could affect the fate of the added strains, despite them being added in equal amounts [166]. The addition of single probiotic strain, however, is a far more common practice [181-183]. Enrichment of copepods with either lyophilized Bacillus clausii and Bacillus pumilus at $10^{6} \mathrm{CFU} / \mathrm{mL}$ for $3 \mathrm{~h}$ improved the growth performance, survival, and desirable gut microbiota of fish larvae [165]. The added probiotic strains are likely to aid in the modulation of intestinal digestive enzymes, lysozyme, and superoxide dismutase activities [165].

Nimrat et al. [184] assessed the effects of different probiotic forms and modes of probiotic administration on postlarval white shrimp (L. vannamei). Bacillus spp. was administered to shrimp culture in the form of freeze-dried, microencapsulated beads, and bioencapsulation of Artemia. Artemia was enriched with microencapsulated Bacillus spp. at $10^{9} \mathrm{CFU} / \mathrm{mL}$ for $6 \mathrm{~h}$. Microencapsulated and 
freeze-dried Bacillus spp. significantly enhanced the growth and survival of post-larval shrimp. In another study, commercial Bacillus spp. was either (1) added directly to the rearing water, and/or (2) with probiotic-enriched Artemia at $2.2 \times 10^{7} \mathrm{CFU} / \mathrm{mL}$ for $10 \mathrm{~h}$ [185]. Both studies suggested that the forms of the probiotic strains and the modes of probiotic administration did not influence the growth and survival of the post-larval shrimp. Moreover, it is important to note that the efficiency of probiotic strains is dependent on the duration of exposure [185]. A study assessed the effects of synbiotic enrichment of zooplankton [186]. Synbiotic enrichment (Pediococcus acidlactici at $700 \mathrm{mg} / \mathrm{L}$ and fructooligosaccharide at $100 \mathrm{mg} / \mathrm{L}$ ) of Artemia significantly improved fish growth performance, microbial diversity, stress tolerance, and immune responses. Besides this, HUFA was also administered along with the probiotic-enriched zooplankton [187]. Administration of HUFA-rich emulsion (cod liver oil) at $0.5 \mathrm{~mL} / \mathrm{L}$ together with commercial L. sporogenes-enriched Artemia at $10 \mathrm{mg} / \mathrm{L}$ for $6 \mathrm{~h}$ and then $12 \mathrm{~h}$ at day 10 improved the survival of prawn larvae. Interestingly, the larvae in the probiotic-enriched group contained DHA at low concentration (0.4\%), while the larvae fed with Artemia enriched with both emulsion and probiotic had the highest contents (4.4\%). It has been reported that Shewanella putrefaciens-enriched Artemia may contribute to the elevation of n-3 HUFA levels in the consuming fish larvae [188]. Added microbiota were proven to regulate the capacity of intestinal absorption and metabolism of fatty acids in fish [189]. The effects of combining a probiotic strain and a bacteriophage were assessed [190]. The addition of $P$. inhibes at $10^{7} \mathrm{CFU} / \mathrm{mL}$ and vibriophage at $10^{7} \mathrm{PFU} / \mathrm{mL}$ was able to inhibit the growth of Vibrio anguillarum and protect Artemia from vibrio infection. However, the interactions between the probiotic strain and vibriophage needed to be further studied as the vibriophage was unable to reduce the mortality of Vibrio-challenged Artemia, despite having the ability to initially lower Vibrio counts in Vibrio treatment alone. Thus, the quick reduction of vibrios in Artemia indicated that phage therapy followed by subsequent addition of probiotic could be a practical approach for controlling vibrios in zooplankton cultures [190].

Enrichment of live food with probiotics allows it to remain viable and proliferate in the live food constituents, and therefore it can be effectively transported into the hosts [191]. Probiotic bacteria are not only able to enhance the nutritional value of live food by providing essential compounds such as vitamins or inorganic nutrients lacking in the diet but are also able increase the population density of live food and inhibit the growth of pathogens [168,178]. Moreover, a direct administration of probiotics to the culture water is risky as they are easily exposed to microbiological contamination [165]. Furthermore, the short survival period of probiotics in seawater makes the utilization of live food as a vector an ideal approach [192]. Since live food stays in the rearing water for a few hours before it can be consumed, the bioencapsulated bacteria should be able to remain in the live food long enough prior to larval feeding [172]. Therefore, it is necessary to assess the rate of loss of the bioencapsulated bacteria and the tenacity of the altered bacterial composition [193]. At the early developmental stage of the fish larvae, the growth in the number of bacteria in the fish intestinal microflora is closely related to the bacteria in the live food [194]. Therefore, the enrichment of live food with probiotics in the bioencapsulation method allows for control of the bacterial population in the live food. This may lead to a better growth performance and survival of the fish and crustacean larvae [194].

In conclusion, the bioencapsulation of live foods such as Artemia, rotifers, and copepods with probiotics is a common approach to deliver probiotics to a wide range of fish and crustacean larvae. Even though the single probiotic strain administration is a far more common practice, several studies showed that the combined administration of two or more probiotic strains is more effective. It is very common to use Bacillus spp. and LAB such as Lactobacillus spp. in larviculture practice. Additionally, it is recommended that an indigenous probiotic strain be utilized, one that includes the normal dominant gastrointestinal microbiota of the host or any of its developmental phases. The application of the indigenous strain would be advantageous in terms of yielding more dominant colonization. Moreover, probiotic strains can also be administered along with prebiotics, HUFA, and bacteriophages to enhance the nutritional status of the zooplankton that consequently may confer health benefits to fish and crustacean larvae. The applications of probiotic-enriched live food in aquaculture are summarized in Table 3. 
Table 3. Enrichment of live food with probiotics.

\begin{tabular}{|c|c|c|c|c|c|}
\hline Probiotic Strains & Live Feed & Biological Model & Method & Effects & References \\
\hline Bacillus spp. & $\begin{array}{c}\text { Copepod Pseudodiaptomus } \\
\text { annandalei }\end{array}$ & Grouper (E. coioides) & $\begin{array}{l}\text { Incubation with individual strain of } \\
\text { lyophilized probiotic for } 3 \mathrm{~h}\end{array}$ & $\begin{array}{l}\text { Growth promoter, survival } \\
\text { improvement, and inhibition of } \\
\text { pathogens }\end{array}$ & [165] \\
\hline Bacillus spp. & Artemia franciscana & $\begin{array}{l}\text { Pacific white shrimp }(L . \\
\text { vannamei) }\end{array}$ & $\begin{array}{c}\text { Incubation with mixed } \\
\text { microencapsulated probiotics for } 6 \mathrm{~h}\end{array}$ & $\begin{array}{l}\text { Growth promoter, survival, and } \\
\text { water quality improvement }\end{array}$ & [184] \\
\hline $\begin{array}{l}\text { Bacillus spp., Debaryomyces hansenii, } \\
\text { Rhodotorula sp., and Chaetoceros sp. }\end{array}$ & A. franciscana & $\begin{array}{l}\text { Pacific white shrimp }(L . \\
\text { vannamei) }\end{array}$ & $\begin{array}{l}\text { Incubation with individual strain of } \\
\text { microencapsulated probiotic for } 6 \mathrm{~h}\end{array}$ & $\begin{array}{l}\text { Growth promoter and survival } \\
\text { improvement }\end{array}$ & [195] \\
\hline $\begin{array}{l}\text { Bacillus subtilis, Lactobacillus sp., } \\
\text { and Lactococcus sp. }\end{array}$ & A. franciscana & - & $\begin{array}{l}\text { Single administration of each probiotic } \\
\text { strain }\end{array}$ & Survival improvement & [196] \\
\hline $\begin{array}{l}\text { B. subtilis, Lactobacillus spp., and } \\
\text { Lactococcus spp. }\end{array}$ & Artemia nauplii & - & $\begin{array}{l}\text { Administration of mixed } 10 \text { probiotic } \\
\text { strains }\end{array}$ & $\begin{array}{l}\text { Inhibition of pathogens and } \\
\text { survival improvement }\end{array}$ & [197] \\
\hline $\begin{array}{l}\text { B. subtilis, Lactobacillus spp., and } \\
\text { Pediococcus spp. }\end{array}$ & $\begin{array}{l}\text { Rotifer B. rotundiformis } \\
\text { and Proales similis }\end{array}$ & - & $\begin{array}{l}\text { Co-feeding a mixture of LAB and } B . \\
\text { subtilis with algae paste }\end{array}$ & Growth promoter & [170] \\
\hline $\begin{array}{c}\text { Bifidobacterium animalis, } \\
\text { Lactobacillus johnsonii, and Bacillus } \\
\text { sp. }\end{array}$ & Artemia metanauplii & $\begin{array}{l}\text { Shortfin silverside (Chirostoma } \\
\text { humboldtianum) }\end{array}$ & $\begin{array}{l}\text { Incubation with individual probiotic } \\
\text { strain for } 40 \mathrm{~min}\end{array}$ & $\begin{array}{l}\text { Growth promoter and survival } \\
\text { improvement }\end{array}$ & [198] \\
\hline Commercial probiotic products & Rotifer B. rotundiformis & - & Co-feeding with N. oculata & Growth promoter & [199] \\
\hline Commercial probiotic products & $\begin{array}{l}\text { Rotifer Brachionus } \\
\text { calyciflorus }\end{array}$ & - & Co-feeding with $C$. vulgaris & Growth promoter & [200] \\
\hline $\begin{array}{l}\text { Commercial probiotic products and } \\
\text { pure isolates }\end{array}$ & Rotifer B. plicatilis & - & $\begin{array}{l}\text { Co-feeding either with artificial diet or } \\
\text { axenic microalgae or both }\end{array}$ & Growth promoter & [168] \\
\hline Escherichia coli & Artemia nauplii & $\begin{array}{l}\text { Black tiger shrimp (Penaeus } \\
\text { monodon) }\end{array}$ & $\begin{array}{l}\text { Enrichment with } E \text {. coli expressing } \\
\text { dsRNA-LSNV for } 2 \mathrm{~h}\end{array}$ & Elimination of viral infection & [201] \\
\hline LAB strains & Rotifer B. plicutilis & - & $\begin{array}{l}\text { Individual or joint addition of several } \\
\text { strains }\end{array}$ & Growth promoter & [171] \\
\hline \multirow[t]{2}{*}{ Lactobacillus sporogenes } & \multirow[t]{2}{*}{ Artemia nauplii } & \multirow{2}{*}{$\begin{array}{l}\text { Freshwater prawn } \\
\text { (Macrobrachium rosenbergii) }\end{array}$} & $\begin{array}{l}\text { Incubation with the lyophilized } \\
\text { probiotic strain for } 12 \mathrm{~h}\end{array}$ & $\begin{array}{l}\text { Growth promoter and survival } \\
\text { improvement }\end{array}$ & [182] \\
\hline & & & $\begin{array}{l}\text { Incubation with the probiotic strain } \\
\text { suspension (sporolac tablet) for } 7 \mathrm{~h}\end{array}$ & Growth promoter & [202] \\
\hline Lactobacillus spp. & $\begin{array}{l}\text { Rotifer B. plicatilis and } A . \\
\quad \text { franciscana }\end{array}$ & $\begin{array}{l}\text { Blue swimming crab (Portunus } \\
\text { pelagicus) }\end{array}$ & $\begin{array}{l}\text { Incubation with a single or multiple } \\
\text { probiotic strain for } 2 \mathrm{~h}\end{array}$ & $\begin{array}{l}\text { Inhibition of pathogens and } \\
\text { survival improvement }\end{array}$ & [175] \\
\hline $\begin{array}{c}\text { Mycobacterium, Ruegeria, } \\
\text { Pseudoalteromonas, and Vibrio }\end{array}$ & $\begin{array}{l}\text { Rotifer Brachionus ibericus } \\
\text { and Artemia nauplii }\end{array}$ & Atlantic cod (G. morhua) & $\begin{array}{l}\text { Incubation with equally mixed } \\
\text { probiotics for } 30 \mathrm{~min}\end{array}$ & $\begin{array}{l}\text { Probiotic strains are only } \\
\text { transiently present in larva }\end{array}$ & [166] \\
\hline
\end{tabular}


Table 3. Cont.

\begin{tabular}{|c|c|c|c|c|c|}
\hline Probiotic Strains & Live Feed & Biological Model & Method & Effects & References \\
\hline Phaeobacter inhibens & A. salina & - & $\begin{array}{c}\text { Co-culture of Artemia, non-axenic algae, } \\
\text { the probiotic strain, and pathogen for } \\
96 \mathrm{~h}\end{array}$ & $\begin{array}{l}\text { Inhibition of pathogens and } \\
\text { survival improvement }\end{array}$ & [190] \\
\hline Phaeobacter sp. & Rotifer B. plicatilis & - & $\begin{array}{l}\text { Enrichment with algae and the } \\
\text { probiotic strain for } 24 \mathrm{~h}\end{array}$ & $\begin{array}{l}\text { High probiont retention for } 48 \mathrm{~h} \\
\text { after enrichment }\end{array}$ & [172] \\
\hline Saccharomyces boulardii & Artemia nauplii & - & $\begin{array}{c}\text { Incubation at } 3 \text { different concentrations } \\
\text { for } 24 \mathrm{~h}\end{array}$ & Survival improvement & [181] \\
\hline Strain 4:44 and PB52 & Rotifer B. plicatilis & Turbot (Scophthalmus maximus) & $\begin{array}{l}\text { Incubation with either a single or } \\
\text { mixed strain for } 20 \mathrm{~min}\end{array}$ & Successful colonization of the gut & [193] \\
\hline Weissiella koreensis & Artemia nauplii & $\begin{array}{c}\text { Stellate sturgeon (Acipenser } \\
\text { stellatus) }\end{array}$ & Incubation for $10 \mathrm{~h}$ & $\begin{array}{l}\text { Growth promoter and survival } \\
\text { improvement }\end{array}$ & [203] \\
\hline
\end{tabular}




\section{Conclusions}

This review focused on the modification of the nutrient composition of zooplankton as live food through supplementation of essential nutrients in culture media before they are fed to fish and crustacean larvae. Live food acts as an important basic diet for larval cultivation, and the availability of appropriate quantities of essential nutrients in the larval diet is crucial to ensure the successful rearing of fish larvae. The enrichment of zooplankton live food through bioencapsulation is convenient to improve the nutritional status of live food for consumption by fish larvae. Encapsulation of nutrient-deficient live food such as rotifers and Artemia with micro- and macro-nutrients has been demonstrated to elevate the dietary value of the live food and to enhance the performance of fish larvae and fries. Rotifers and Artemia are commonly enriched with micro-nutrients to meet the copepod nutrient levels, which are frequently used as reference to indicate larval dietary requirements. The nutritional profile of copepods can be altered through changes in dietary algal nutrition by the pre-enrichment of algae with various essential nutrients. Even though live food is considered as "living capsules of nutrition", further evaluations are needed to establish the stability and the high retention rate of nutrients in live food to ensure the intended quantity is successfully delivered to larval fish and crustaceans. On the basis of the literature we reviewed, we suggest that sustainable and effective larval rearing can be achieved, and with better understanding of the enrichment techniques, other sources of feed may gradually be used as substitutes to live food.

Author Contributions: Writing—original draft preparation, N.A.S.; writing—review and editing, M.K., F.M.Y., and N.W.R.; visualization, N.A.S.; supervision, M.K.; funding acquisition, M.K. All authors have read and agreed to the published version of the manuscript.

Funding: This research was funded by the Ministry of Higher Education Malaysia (MOHE) through SATREPS JICA-JST COSMOS (Continuous Operation System for Microalgae Production Optimized for Sustainable Tropical Aquaculture) 2016-2021; Higher Institution Centre of Excellence (HiCoE) grant of Innovative Vaccine and Therapeutics against Fish Diseases, vote no. 6369100; and the Ministry of Education Malaysia under the Long Research Grant Scheme LRGS/1/2019/UPM/1 and the Fundamental Research Grant Scheme FRGS/1/2020/WAB04/UPM/02/9.

Acknowledgments: The first author was under a sponsorship scheme by the Perak state government.

Conflicts of Interest: The authors declare no conflict of interest. The funders had no role in the design of the study; in the collection, analyses, or interpretation of data; in the writing of the manuscript; or in the decision to publish the results.

\section{References}

1. Sontakke, R.; Chaturvedi, C.S.; Saharan, N.; Tiwari, V.K.; Haridas, H.; Rani, A.B. Growth response, digestive enzyme activity and stress enzyme status in early stages of an endangered fish, Notopterus chitala (Hamilton, 1822) fed with live feed and formulated diet. Aquaculture 2019, 510, 182-190. [CrossRef]

2. Simhachalam, G.; Kumar, N.S.; Rao, K.G. Biochemical composition and nutritional value of Streptocephalus simplex as live feed in ornamental fish culture. J. Basic Appl. Zool. 2015, 72, 66-72. [CrossRef]

3. Zeng, C.; Shao, L; Ricketts, A.; Moorhead, J. The importance of copepods as live feed for larval rearing of the green mandarin fish Synchiropus splendidus. Aquaculture 2018, 491, 65-71. [CrossRef]

4. Olivotto, I.; Planas, M.; Simões, N.; Holt, G.J.; Avella, M.A.; Calado, R. Advances in breeding and rearing marine ornamentals. J. World Aquac. Soc. 2011, 42, 135-166. [CrossRef]

5. Mondal, A.; Aziz, A.; Joysowal, M.; Chirwatkar, B. Importance of live feed in aquaculture. Int. J. Sci. Res. Dev. 2018, 6, 656-658.

6. Rasdi, N.W.; Qin, J.G. Improvement of copepod nutritional quality as live food for aquaculture: A review. Aquac. Res. 2016, 47, 1-20. [CrossRef]

7. Radhakrishnan, D.K.; AkbarAli, I.; Schmidt, B.V.; John, E.M.; Sivanpillai, S.; Vasunambesan, S.T. Improvement of nutritional quality of live feed for aquaculture: An overview. Aquac. Res. 2020, 51, 1-17. [CrossRef]

8. Das, P.; Mandal, S.C.; Bhagabati, S.K.; Akhtar, M.S.; Singh, S.K. Important live food organisms and their role in aquaculture. In Frontiers in Aquaculture, 1st ed.; Sundaray, J.K., Mohanty, R.K., Sukham, M., Otta, S.K., Eds.; Narendra Publishing House: Delhi, India, 2012; pp. 69-86. [CrossRef] 
9. Cahu, C.; Zambonino-Infante, J. Substitution of live food by formulated diets in marine fish larvae. Aquaculture 2001, 200, 161-180. [CrossRef]

10. Sáez-Royuela, M.; Carral, J.M.; Celada, J.D.; Pérez, J.R.; González, A. Live feed as supplement from the onset of external feeding of juvenile signal crayfish (Pacifastacus leniusculus Dana. Astacidae) under controlled conditions. Aquaculture 2007, 269, 321-327. [CrossRef]

11. Yanes-Roca, C.; Mráz, J.; Born-Torrijos, A.; Holzer, A.S.; Imentai, A.; Policar, T. Introduction of rotifers (Brachionus plicatilis) during pikeperch first feeding. Aquaculture 2018, 497, 260-268. [CrossRef]

12. Jones, D.A.; Kamarudin, M.S.; Le Vay, L. The potential for replacement of live feeds in larval culture. J. World Aquac. Soc. 1993, 24, 199-210. [CrossRef]

13. Curnow, J.; King, J.; Bosmans, J.; Kolkovski, S. The effect of reduced Artemia and rotifer use facilitated by a new microdiet in the rearing of barramundi Lates calcarifer (Bloch) larvae. Aquaculture 2006, 257, 204-213. [CrossRef]

14. Waagbø, R. Feeding and disease resistance in fish. In Biology of Nutritionin Growing Animals; Mosenthin, R., Zenek, J., Zebrowska, T., Eds.; Elsevier Ltd.: London, UK, 2006; Volume 4, pp. 387-415. [CrossRef]

15. Cavrois-Rogacki, T.; Rolland, A.; Migaud, H.; Davie, A.; Monroig, O. Enriching Artemia nauplii with selenium from different sources and interactions with essential fatty acid incorporation. Aquaculture 2020, 520, 734677. [CrossRef]

16. Eryalçın, K.M. Nutritional value and production performance of the rotifer Brachionus plicatilis Müller, 1786 cultured with different feeds at commercial scale. Aquac. Int. 2019, 27, 875-890. [CrossRef]

17. Giménez, G.; Kotzamanis, Y.; Hontoria, F.; Estévez, A.; Gisbert, E. Modelling retinoid content in live prey: A tool for evaluating the nutritional requirements and development studies in fish larvae. Aquaculture 2007, 267, 76-82. [CrossRef]

18. Ribeiro, A.R.; Rebeiro, L.; Sæle, Ø.; Hamre, K.; Dinis, M.T.; Moren, M. Iodine-enriched rotifers and Artemia prevent goitre in Senegalese sole (Solea senegalensis) larvae reared in a recirculation system. Aquac. Nutr. 2011, 17, 248-257. [CrossRef]

19. Singh, K.; Munilkumar, S.; Sahu, N.P.; Das, A.; Devi, G.A. Feeding HUFA and vitamin C-enriched Moina micrura enhances growth and survival of Anabas testudineus (Bloch, 1792) larvae. Aquaculture 2019, 500, 378-384. [CrossRef]

20. Sun, S.; Chen, L.; Ge, X.; Qin, J. Examination of a practical method for copper enrichment of euryhaline rotifers (Brachionus plicatilis) as diet of Eriocheir sinensis zoea larvae. Aquac. Nutr. 2013, 19, 809-817. [CrossRef]

21. Ljubobratovic, U.; Kosanovic, D.; Demény, F.Z.; Krajcsovics, A.; Vukotic, G.; Stanisavljevic, N.; Golic, N.; Jeney, G.; Lukic, J. The effect of live and inert feed treatment with lactobacilli on weaning success in intensively reared pike-perch larvae. Aquaculture 2020, 516, 734608. [CrossRef]

22. Penglase, S.; Nordgreen, A.; van der Meeren, T.; Olsvik, P.A.; Sæle, Ø.; Sweetman, J.W.; Baeverfjord, G.; Helland, S.; Hamre, K. Increasing the level of selenium in rotifers (Brachionus plicatilis 'Cayman') enhances the mRNA expression and activity of glutathione peroxidase in cod (Gadus morhua L.) larvae. Aquaculture 2010, 306, 259-269. [CrossRef]

23. Rehberg-Haas, S.; Meyer, S.; Tielmann, M.; Lippemeier, S.; Vadstein, O.; Bakke, I.; Kjørsvik, E.; Evjemo, J.O.; Schulz, C. Use of the microalga Pavlova viridis as enrichment product for the feeding of Atlantic cod larvae (Gadus morhua). Aquaculture 2015, 438, 141-150. [CrossRef]

24. Roo, J.; Hernández-Cruz, C.M.; Mesa-Rodriguez, A.; Fernández-Palacios, H.; Izquierdo, M.S. Effect of increasing n-3 HUFA content in enriched Artemia on growth, survival and skeleton anomalies occurrence of greater amberjack Seriola dumerili larvae. Aquaculture 2019, 500, 651-659. [CrossRef]

25. Park, H.G.; Puvanendran, V.; Kellett, A.; Parrish, C.C.; Brown, J.A. Effect of enriched rotifers on growth, survival, and composition of larval Atlantic cod (Gadus morhua). ICES J. Mar. Sci. 2006, 63, 285-295. [CrossRef]

26. Tocher, D.R. Fatty acid requirements in ontogeny of marine and freshwater fish. Aquac. Res. 2010, 41, 717-732. [CrossRef]

27. Kertaoui, N.E.; Hernández-Cruz, C.M.; Montero, D.; Caballero, M.J.; Saleh, R.; Afonso, J.M.; Izquierdo, M. The importance of dietary HUFA for meagre larvae (Argyrosomus regius; Asso, 1801) and its relation with antioxidant vitamins E and C. Aquac. Res. 2017, 48, 419-433. [CrossRef] 
28. Koven, W.; Barr, Y.; Lutzky, S.; Ben-Atia, I.; Weiss, R.; Harel, M.; Behrens, P.; Tandler, A. The effect of dietary arachidonic acid (20:4n-6) on growth, survival and resistance to handling stress in gilthead seabream (Sparus aurata) larvae. Aquaculture 2001, 193, 107-122. [CrossRef]

29. Li, M.; Xu, C.; Ma, Y.; Ye, R.; Chen, H.; Xie, D.; Zhang, G.; Zhang, M.; Wang, M.; You, C.; et al. Effects of dietary n-3 highly unsaturated fatty acids levels on growth, lipid metabolism and innate immunity in juvenile golden pompano (Trachinotus ovatus). Fish. Shellfish Immunol. 2020, 105, 177-185. [CrossRef]

30. Milián-Sorribes, M.C.; Martínez-Llorens, S.; Cruz-Castellón, C.; Jover-Cerdá, M.; Tomás-Vidal, A. Effect of fish oil replacement and probiotic addition on growth, body composition and histological parameters of yellowtail (Seriola dumerili). Aquac. Nutr. 2020. [CrossRef]

31. Rasdi, N.W.; Qin, J.G. Copepod supplementation as live food improved growth and survival of Asian seabass Lates calcarifer larvae. Aquac. Res. 2018, 49, 3606-3613. [CrossRef]

32. An, W.; He, H.; Dong, X.; Tan, B.; Yang, Q.; Chi, S.; Zhang, S.; Liu, H.; Yang, Y. Regulation of growth, fatty acid profiles, hematological characteristics and hepatopancreatic histology by different dietary n-3 highly unsaturated fatty acids levels in the first stages of juvenile Pacific white shrimp (Litopenaeus vannamei). Aquac. Rep. 2020, 17, 100321. [CrossRef]

33. Bell, J.G.; McEvoy, L.A.; Estevez, A.; Shields, R.J.; Sargent, J.R. Optimising lipid nutrition in first-feeding flatfish larvae. Aquaculture 2003, 227, 211-220. [CrossRef]

34. Eryalçın, K.M. Effects of different commercial feeds and enrichments on biochemical composition and fatty acid profile of rotifer (Brachionus plicatilis, Müller 1786) and Artemia franciscana. Turk. J. Fish. Aquat. Sci. 2018, 18, 81-90. [CrossRef]

35. Guinot, D.; Monroig, Ó.; Hontoria, F.; Amat, F.; Varó, I.; Navarro, J.C. Enriched on-grown Artemia metanauplii actively metabolise highly unsaturated fatty acid-rich phospholipids. Aquaculture 2013, 412-413, 173-178. [CrossRef]

36. Hamre, K. Nutrient profiles of rotifers (Brachionus sp.) and rotifer diets from four different marine fish hatcheries. Aquaculture 2016, 450, 136-142. [CrossRef]

37. Kotani, T.; Genka, T.; Tanabe, M.; Miyashima, A.; Fushimi, H.; Hayashi, M. Effect of nutritional enrichment method on fatty acid contents of rotifer Brachionus plicatilis. J. World Aquac. Soc. 2010, 41, 884-892. [CrossRef]

38. McEvoy, L.A.; Naess, T.; Bell, J.G.; Lie, Ø. Lipid and fatty acid composition of normal and malpigmented Atlantic halibut (Hippoglossus hippoglossus) fed enriched Artemia: A comparison with fry fed wild copepods. Aquaculture 1998, 163, 237-250. [CrossRef]

39. Payne, M.F.; Rippingale, R.J. Rearing West Australian seahorse, Hippocampus subelongatus, juveniles on copepod nauplii and enriched Artemia. Aquaculture 2000, 188, 353-361. [CrossRef]

40. Villalta, M.; Estévez, A.; Bransden, M.P. Arachidonic acid enriched live prey induces albinism in Senegal sole (Solea senegalensis) larvae. Aquaculture 2005, 245, 193-209. [CrossRef]

41. Evjemo, J.O.; Olsen, Y. Lipid and fatty acid content in cultivated live feed organisms compared to marine copepods. Hydrobiologia 1997, 358, 159-162. [CrossRef]

42. Van der Meeren, T.; Olsen, R.E.; Hamre, K.; Fyhn, H.J. Biochemical composition of copepods for evaluation of feed quality in production of juvenile marine fish. Aquaculture 2008, 274, 375-397. [CrossRef]

43. Matsunari, H.; Hashimoto, H.; Oda, K.; Masuda, Y.; Imaizumi, H.; Teruya, K.; Furuita, H.; Yamamoto, T.; Hamada, K.; Mushiake, K. Effects of docosahexaenoic acid on growth, survival and swim bladder inflation of larval amberjack (Seriola dumerili, Risso). Aquac. Res. 2013, 44, 1696-1705. [CrossRef]

44. Rodríguez, C.; Pérez, J.A.; Díaz, M.; Izquierdo, M.S.; Fernández-Palacios, H.; Lorenzo, A. Influence of the EPA/DHA ratio in rotifers on gilthead seabream (Sparus aurata) larval development. Aquaculture 1997, 150, 77-89. [CrossRef]

45. Olsen, A.I.; MÆland, A.; WaagbØ, R.; Olsen, Y. Effect of algal addition on stability of fatty acids and some water-soluble vitamins in juvenile Artemia franciscana. Aquac. Nutr. 2000, 6, 263-273. [CrossRef]

46. Li, H.; Liu, J. Effects of defatted Haematococcus pluvialis meal (DHPM) supplementation on the growth performance, and the carotenoid content and composition in the rotifer (Brachionus plicatilis). Aquaculture 2019, 505, 34-40. [CrossRef]

47. Thinh, L.V.; Renaud, S.M.; Parry, D.L. Evaluation of recently isolated Australian tropical microalgae for the enrichment of the dietary value of brine shrimp, Artemia nauplii. Aquaculture 1999, 170, 161-173. [CrossRef] 
48. Seixas, P.; Rey-Méndez, M.; Valente, L.M.; Otero, A. Producing juvenile Artemia as prey for Octopus vulgaris paralarvae with different microalgal species of controlled biochemical composition. Aquaculture 2008, 283, 83-91. [CrossRef]

49. Seixas, P.; Coutinho, P.; Ferreira, M.; Otero, A. Nutritional value of the cryptophyte Rhodomonas lens for Artemia sp. J. Exp. Mar. Biol. Ecol. 2009, 381, 1-9. [CrossRef]

50. Carotenuto, Y.; Ianora, A.; Miralto, A. Maternal and neonate diatom diets impair development and sex differentiation in the copepod Temora stylifera. J. Exp. Mar. Biol. Ecol. 2011, 396, 99-107. [CrossRef]

51. Dhanker, R.; Kumar, R.; Hwang, J.S. Predation by Pseudodiaptomus annandalei (Copepoda: Calanoida) on rotifer prey: Size selection, egg predation and effect of algal diet. J. Exp. Mar. Biol. Ecol. 2012, 414-415, 44-53. [CrossRef]

52. Matias-Peralta, H.M.; Yusoff, F.M.; Shariff, M.; Mohamed, S. Reproductive performance, growth and development time of a tropical harpacticoid copepod, Nitocra affinis californica Lang, 1965 fed with different microalgal diets. Aquaculture 2012, 344-349, 168-173. [CrossRef]

53. Ohs, C.L.; Chang, K.L.; Grabe, S.W.; DiMaggio, M.A.; Stenn, E. Evaluation of dietary microalgae for culture of the calanoid copepod Pseudodiaptomus pelagicus. Aquaculture 2010, 307, 225-232. [CrossRef]

54. Ribeiro, A.C.; Souza-Santos, L.P. Mass culture and offspring production of marine harpacticoid copepod Tisbe biminiensis. Aquaculture 2011, 321, 280-288. [CrossRef]

55. Siqwepu, O.; Richoux, N.B.; Vine, N.G. The effect of different dietary microalgae on the fatty acid profile, fecundity and population development of the calanoid copepod Pseudodiaptomus hessei (Copepoda: Calanoida). Aquaculture 2017, 468 Pt 1, 162-168. [CrossRef]

56. Zhang, J.; Wu, C.; Pellegrini, D.; Romano, G.; Esposito, F.; Ianora, A.; Buttino, I. Effects of different monoalgal diets on egg production, hatching success and apoptosis induction in a Mediterranean population of the calanoid copepod Acartia tonsa (Dana). Aquaculture 2013, 400-401, 65-72. [CrossRef]

57. Farhadian, O.; Yusoff, F.M.; Mohamed, S.; Saad, C.R. Use of cyclopoid copepod Apocyclops dengizicus as live feed for Penaeus monodon postlarvae. J. World Aquac. Soc. 2009, 40, 22-32. [CrossRef]

58. Azuraidi, O.M.; Yusoff, F.M.; Shamsudin, M.N.; Raha, R.A.; Alekseev, V.R.; Matias-Peralta, H.M. Effect of food density on male appearance and ephippia production in a tropical cladoceran, Moina micrura Kurz, 1874. Aquaculture 2013, 412-413, 131-135. [CrossRef]

59. Mourente, G.; Rodriguez, A.; Tocher, D.R.; Sargent, J.R. Effects of dietary docosahexaenoic acid (DHA;22:6n-3) on lipid and fatty acid compositions and growth in gilthead sea bream (Sparus aurata L.) larvae during first feeding. Aquaculture 1993, 112, 79-98. [CrossRef]

60. Sukenik, A.; Zmora, O.; Carmeli, Y. Biochemical quality of marine unicellular algae with special emphasis on lipid composition: II. Nannochloropsis sp. Aquaculture 1993, 117, 313-326. [CrossRef]

61. Shields, R.J. Larviculture of marine finfish in Europe. Aquaculture 2001, 200, 55-88. [CrossRef]

62. Spolaore, P.; Joannis-Cassan, C.; Duran, E.; Isambert, A. Commercial applications of microalgae. J. Biosci. Bioeng. 2006, 101, 87-96. [CrossRef]

63. Raja, R.; Coelho, A.; Hemaiswarya, S.; Kumar, P.; Carvalho, I.S.; Alagarsamy, A. Applications of microalgal paste and powder as food and feed: An update using text mining tool. Beni Suef Univ. J. Basic Appl. Sci. 2018, 7, 740-747. [CrossRef]

64. Thépot, V.; Mangott, A.; Pirozzi, I. Rotifers enriched with a mixed algal diet promote survival, growth and development of barramundi larvae, Lates calcarifer (Bloch). Aquac. Rep. 2016, 3, 147-158. [CrossRef]

65. Copeman, L.A.; Parrish, C.C.; Brown, J.A.; Harel, M. Effects of docosahexaenoic, eicosapentaenoic, and arachidonic acids on the early growth, survival, lipid composition and pigmentation of yellowtail flounder (Limanda ferruginea): A live food enrichment experiment. Aquaculture 2002, 210, 285-304. [CrossRef]

66. Dhert, P.; Rombaut, G.; Suantika, G.; Sorgeloos, P. Advancement of rotifer culture and manipulation techniques in Europe. Aquaculture 2001, 200, 129-146. [CrossRef]

67. Rainuzzo, J.R.; Reitan, K.I.; Olsen, Y. Effect of short- and long-term lipid enrichment on total lipids, lipid class and fatty acid composition in rotifers. Aquac. Int. 1994, 2, 19-32. [CrossRef]

68. Li, K.; Olsen, Y. Effect of enrichment time and dietary DHA and non-highly unsaturated fatty acid composition on the efficiency of DHA enrichment in phospholipid of rotifer (Brachionus Cayman). Aquaculture 2015, 446, 310-317. [CrossRef]

69. Baer, A.; Langdon, C.; Mills, S.; Schulz, C.; Hamre, K. Particle size preference, gut filling and evacuation rates of the rotifer Brachionus "Cayman" using polystyrene latex beads. Aquaculture 2008, 282, 75-82. [CrossRef] 
70. Romero-Romero, S.; Yúfera, M. Contribution of gut content to the nutritional value of Brachionus plicatilis used as prey in larviculture. Aquaculture 2012, 364-365, 124-129. [CrossRef]

71. Stuart, K.R.; Drawbridge, M. The effect of light intensity and green water on survival and growth of cultured larval California yellowtail (Seriola lalandi). Aquaculture 2011, 321, 152-156. [CrossRef]

72. Akbary, P.; Hosseini, S.A.; Imanpoor, M.R. Enrichment of Artemia nauplii with essential fatty acids and vitamin C: Effect on rainbow trout (Oncorhynchus mykiss) larvae performance. Iran. J. Fish. Sci. 2011, 10, 557-569.

73. Kamaszewski, M.; Ostaszewska, T.; Prusińska, M.; Kolman, R.; Chojnacki, M.; Zabytyvskij, J.; Jankowska, B.; Kasprzak, R. Effects of Artemia sp. enrichment with essential fatty acids on functional and morphological aspects of the digestive system in Acipenser gueldenstaedtii larvae. Turk. J. Fish. Aquat. Sci. 2014, 14, 929-938. [CrossRef]

74. Kamaszewski, M.; Wójcik, M.; Ostaszewska, T.; Kasprzak, R.; Kolman, R.; Prusiñska, M. The effect of essential fatty acid (EFA) enrichment of Artemia sp. nauplii on the enzymatic activity of Atlantic sturgeon (Acipenser oxyrinchus Mitchill, 1815) larvae-Preliminary study. J. Appl. Ichthyol. 2014, 30, 1256-1258. [CrossRef]

75. Fereidouni, A.E.; Fathi, N.; Khalesi, M.K. Enrichment of Daphnia magna with canola oil and its effects on the growth, survival and stress resistance of the caspian kutum (Rutilus frisii kutum) larvae. Turk. J. Fish. Aquat. Sci. 2013, 13, 119-123. [CrossRef]

76. Gholami, M. Effects of n-3 HUFA enriched Daphnia magna on growth, survival, stress resistance and fatty acid composition of white fish fry (Rutilus frisii kutum). J. Fish. Aquat. Sci. 2010, 5, 49-55. [CrossRef]

77. Gapasin, R.S.; Duray, M.N. Effects of DHA-enriched live food on growth, survival and incidence of opercular deformities in milkfish (Chanos chanos). Aquaculture 2001, 193, 49-63. [CrossRef]

78. Ai, Q.; Mai, K.; Zhang, C.; Xu, W.; Duan, Q.; Tan, B.; Liufu, Z. Effects of dietary vitamin C on growth and immune response of Japanese seabass, Lateolabrax japonicus. Aquaculture 2004, 242, 489-500. [CrossRef]

79. Shahkar, E.; Yun, H.; Kim, D.-J.; Kim, S.-K.; Lee, B.I.; Bai, S.C. Effects of dietary vitamin C levels on tissue ascorbic acid concentration, hematology, non-specific immune response and gonad histology in broodstock Japanese eel, Anguilla japonica. Aquaculture 2015, 438, 115-121. [CrossRef]

80. Asaikkutti, A.; Bhavan, P.S.; Vimala, K.; Karthik, M.; Cheruparambath, P. Effect of different levels dietary vitamin $C$ on growth performance, muscle composition, antioxidant and enzyme activity of freshwater prawn, Macrobrachium malcolmsonii. Aquac. Rep. 2016, 3, 229-236. [CrossRef]

81. Sarmento, N.L.A.F.; Martins, E.F.F.; Costa, D.C.; Mattioli, C.C.; da Costa Julio, G.S.; Figueiredo, L.G.; Luz, M.R.; Luz, R.K. Reproductive efficiency and egg and larvae quality of Nile tilapia fed different levels of vitamin C. Aquaculture 2018, 482, 96-102. [CrossRef]

82. Wahli, T.; Verlhac, V.; Girling, P.; Gabaudan, J.; Aebischer, C. Influence of dietary vitamin C on the wound healing process in rainbow trout (Oncorhynchus mykiss). Aquaculture 2003, 225, 371-386. [CrossRef]

83. Ortuño, J.; Esteban, M.A.; Meseguer, J. The effect of dietary intake of vitamins $C$ and $E$ on the stress response of gilthead seabream (Sparus aurata L.). Fish. Shellfish Immunol. 2003, 14, 145-156. [CrossRef] [PubMed]

84. Nguyen, B.T.; Koshio, S.; Sakiyama, K.; Harakawa, S.; Gao, J.; Mamauag, R.E.; Ishikawa, M.; Yokoyama, S. Effects of dietary vitamins $\mathrm{C}$ and $\mathrm{E}$ and their interactions on reproductive performance, larval quality and tissue vitamin contents in kuruma shrimp, Marsupenaeus japonicus Bate. Aquaculture 2012, 334-337, 73-81. [CrossRef]

85. Adloo, M.N.; Matinfar, A.; Sourinezhad, I. Effects of feeding enriched Artemia fransiscana with HUFA, vitamin $\mathrm{C}$ and $\mathrm{E}$ on growth performance, survival and stress resistance of yellowfin seabream larvae. J. Aquac. Res. Dev. 2012, 3, 1000157. [CrossRef]

86. Gao, J.; Koshio, S.; Ishikawa, M.; Yokoyama, S.; Mamauag, R.E. Interactive effects of vitamin C and E supplementation on growth performance, fatty acid composition and reduction of oxidative stress in juvenile Japanese flounder Paralichthys olivaceus fed dietary oxidized fish oil. Aquaculture 2014, 422-423, 84-90. [CrossRef]

87. He, H.; Lawrence, A.L. Vitamin C requirements of the shrimp Penaeus vannamei. Aquaculture 1993, 114, 305-316. [CrossRef]

88. Zhou, Q.; Wang, L.; Wang, H.; Xie, F.; Wang, T. Effect of dietary vitamin C on the growth performance and innate immunity of juvenile cobia (Rachycentron canadum). Fish. Shellfish Immunol. 2012, 32, 969-975. [CrossRef] 
89. Fracalossi, D.M.; Allen, M.E.; Yuyama, L.K.; Oftedal, O.T. Ascorbic acid biosynthesis in Amazonian fishes. Aquaculture 2001, 192, 321-332. [CrossRef]

90. Brown, M.R.; Hohmann, S. Effects of irradiance and growth phase on the ascorbic acid content of Isochrysis sp. T.ISO (Prymnesiophyta). J. Appl. Phycol. 2002, 14, 211-214. [CrossRef]

91. Merchie, G.; Lavens, P.; Dhert, P.; Dehasque, M.; Nelis, H.; De Leenheer, A.; Sorgeloos, P. Variation of ascorbic acid content in different live food organisms. Aquaculture 1995, 134, 325-337. [CrossRef]

92. Gapasin, R.S.; Bombeo, R.; Lavens, P.; Sorgeloos, P.; Nelis, H. Enrichment of live food with essential fatty acids and vitamin C: Effects on milkfish (Chanos chanos) larval performance. Aquaculture 1998, 162, 269-286. [CrossRef]

93. Jiménez-Fernández, E.; Ponce, M.; Rodríguez-Rúa, A.; Manchado, M.; Fernández-Díaz, C. Assessing the role of vitamin C and iron in early larvae stages of Solea senegalensis fed enriched Artemia. Aquaculture 2018, 488, 145-154. [CrossRef]

94. Hernández, J.; Uriarte, I.; de Oca, M.M.; Farías, A. On the relevance of vitamins C and E during embryonic and paralarval development of Patagonian red octopus Enteroctopus megalocyathus. Aquaculture 2019, 501, 502-506. [CrossRef]

95. Lie, O.; Haaland, H.; Hemre, G.-I.; Maage, A.; Lied, E.; Rosenlund, G.; Sandnes, K.; Olsen, Y. Nutritional composition of rotifers following a change in diet from yeast and emulsified oil to microalgae. Aquac. Int. 1997, 5, 427-438. [CrossRef]

96. Sipaúba-Tavares, L.H.; Bachion, M.A.; de Souza Braga, F.M. Effects of food quality on growth and biochemical composition of a calanoid copepod, Argyrodiaptomus furcatus, and its importance as a natural food source for larvae of two tropical fishes. Hydrobiologia 2001, 453, 393-401. [CrossRef]

97. Brown, M.R.; Mular, M.; Miller, I.; Farmer, C.; Trenerry, C. The vitamin content of microalgae used in aquaculture. J. Appl. Phycol. 1999, 11, 247-255. [CrossRef]

98. Sándor, Z.J.; Papp, Z.B.; Ardó, L.; Biro, J.N.; Jeney, G. Effectiveness of dietary vitamin supplementation to the performance of common carp (Cyprinus carpio L.) larvae in intensive rearing condition. Aquac. Res. 2018, 49, 738-747. [CrossRef]

99. Negm, R.K.; Cobcroft, J.M.; Brown, M.R.; Nowak, B.F.; Battaglene, S.C. The effects of dietary vitamin A in rotifers on the performance and skeletal abnormality of striped trumpeter Latris lineata larvae and post larvae. Aquaculture 2013, 404-405, 105-115. [CrossRef]

100. Fernández, I.; Hontoria, F.; Ortiz-Delgado, J.B.; Kotzamanis, Y.; Estévez, A.; Zambonino-Infante, J.L.; Gisbert, E. Larval performance and skeletal deformities in farmed gilthead sea bream (Sparus aurata) fed with graded levels of Vitamin A enriched rotifers (Brachionus plicatilis). Aquaculture 2008, 283, 102-115. [CrossRef]

101. Hernández-H, L.H.; Teshima, S.; Koshio, S.; Ishikawa, M.; Gallardo-Cigarroa, F.J.; Alam, M.S.; Uyan, O. Effects of vitamin A palmitate, beta-carotene and retinoic acid on the growth and incidence of deformities in larvae of red sea bream Chrysophrys major. Cienc. Mar. 2006, 32, 195-204. [CrossRef]

102. Mazurais, D.; Glynatsi, N.; Darias, M.J.; Christodoulopoulou, S.; Cahu, C.L.; Zambonino-Infante, J.-L.; Koumoundouros, G. Optimal levels of dietary vitamin A for reduced deformity incidence during development of European sea bass larvae (Dicentrarchus labrax) depend on malformation type. Aquaculture 2009, 294, 262-270. [CrossRef]

103. Haga, Y.; Suzuki, T.; Kagechika, H.; Takeuchi, T. A retinoic acid receptor-selective agonist causes jaw deformity in the Japanese flounder, Paralichthys olivaceus. Aquaculture 2003, 221, 381-392. [CrossRef]

104. Suzuki, T.; Srivastava, A.S.; Kurokawa, T. Experimental induction of jaw, gill and pectoral fin malformations in Japanese flounder, Paralichthys olivaceus, larvae. Aquaculture 2000, 185, 175-187. [CrossRef]

105. Martinez, G.M.; Baron, M.P.; Bolker, J.A. Skeletal and pigmentation defects following retinoic acid exposure in larval summer flounder, Paralichthys dentatus. J. World Aquac. Soc. 2007, 38, 353-366. [CrossRef]

106. Guimarães, I.G.; Lim, C.; Yildirim-Aksoy, M.; Li, M.H.; Klesius, P.H. Effects of dietary levels of vitamin A on growth, hematology, immune response and resistance of Nile tilapia (Oreochromis niloticus) to Streptococcus iniae. Anim. Feed Sci. Technol. 2014, 188, 126-136. [CrossRef]

107. Yang, Q.; Ding, M.; Tan, B.; Dong, X.; Chi, S.; Zhang, S.; Liu, H. Effects of dietary vitamin A on growth, feed utilization, lipid metabolism enzyme activities, and fatty acid synthase and hepatic lipase mRNA expression levels in the liver of juvenile orange spotted grouper, Epinephelus coioides. Aquaculture 2017, 479, 501-507. [CrossRef] 
108. Shao, L.; Zhu, X.; Yang, Y.; Jin, J.; Liu, H.; Han, D.; Xie, S. Effects of dietary vitamin A on growth, hematology, digestion and lipometabolism of on-growing gibel carp (Carassius auratus gibelio var. CAS III). Aquaculture 2016, 460, 83-89. [CrossRef]

109. Fontagné-Dicharry, S.; Lataillade, E.; Surget, A.; Brèque, J.; Zambonino-Infante, J.; Kaushik, S.J. Effects of dietary vitamin A on broodstock performance, egg quality, early growth and retinoid nuclear receptor expression in rainbow trout (Oncorhynchus mykiss). Aquaculture 2010, 303, 40-49. [CrossRef]

110. Haga, Y.; Takeuchi, T.; Seikai, T. Influence of all-trans retinoic acid on pigmentation and skeletal formation in larval Japanese flounder. Fish. Sci. 2002, 68, 560-570. [CrossRef]

111. Sæle, Ø.; Solbakken, J.S.; Watanabe, K.; Hamre, K.; Pittman, K. The effect of diet on ossification and eye migration in Atlantic halibut larvae (Hippoglossus hippoglossus L.). Aquaculture 2003, 220, 683-696. [CrossRef]

112. Rønnestad, I.; Hemre, G.-I.; Finn, R.N.; Lie, Ø. Alternative sources and dynamics of vitamin A and its incorporation into the eyes during the early endotrophic and exotrophic larval stages of Atlantic halibut (Hippoglossus hippoglossus L.). Comp. Biochem. Physiol. Part A Mol. Integr. Physiol. 1998, 119, 787-793. [CrossRef]

113. Hamre, K.; Srivastava, A.; RØnnestad, I.; Mangor-Jensen, A.; Stoss, J. Several micronutrients in the rotifer Brachionus sp. may not fulfil the nutritional requirements of marine fish larvae. Aquac. Nutr. 2008, 14, 51-60. [CrossRef]

114. Srivastava, A.; Stoss, J.; Hamre, K. A study on enrichment of the rotifer Brachionus "Cayman" with iodine and selected vitamins. Aquaculture 2011, 319, 430-438. [CrossRef]

115. Monroig, Ó.; Navarro, J.C.; Amat, F.; Hontoria, F. Enrichment of Artemia nauplii in vitamin A, vitamin C and methionine using liposomes. Aquaculture 2007, 269, 504-513. [CrossRef]

116. Takeuchi, T.; Dedi, J.; Haga, Y.; Seikai, T.; Watanabe, T. Effect of vitamin A compounds on bone deformity in larval Japanese flounder (Paralichthys olivaceus). Aquaculture 1998, 169, 155-165. [CrossRef]

117. Mitra, G.; Mukhopadhyay, P.K. Dietary essentiality of ascorbic acid in rohu larvae: Quantification with ascorbic acid enriched zooplankton. Aquac. Int. 2003, 11, 81-93. [CrossRef]

118. Negm, R.K.; Cobcroft, J.M.; Brown, M.R.; Nowak, B.F.; Battaglene, S.C. Performance and skeletal abnormality of striped trumpeter Latris lineata larvae and post larvae fed vitamin A enriched Artemia. Aquaculture 2014, 422-423, 115-123. [CrossRef]

119. Fernández, I.; López-Joven, C.; Andree, K.B.; Roque, A.; Gisbert, E. Vitamin A supplementation enhances Senegalese sole (Solea senegalensis) early juvenile's immunocompetence: New insights on potential underlying pathways. Fish. Shellfish Immunol. 2015, 46, 703-709. [CrossRef]

120. Lie, K.K.; Kvalheim, K.; Rasinger, J.D.; Harboe, T.; Nordgreen, A.; Moren, M. Vitamin A and arachidonic acid altered the skeletal mineralization in Atlantic cod (Gadus morhua) larvae without any interactions on the transcriptional level. Comp. Biochem. Physiol. Part A Mol. Integr. Physiol. 2016, 191, 80-88. [CrossRef]

121. Juhász, P.; Lengyel, S.; Udvari, Z.; Sándor, A.N.; Stündl, L. Optimised selenium enrichment of Artemia sp. feed to improve red drum (Sciaenops Ocellatus) larvae rearing. Acta Biol. Hung. 2017, 68, 255-266. [CrossRef]

122. Tapiero, H.; Townsend, D.M.; Tew, K.D. The antioxidant role of selenium and seleno-compounds. Biomed. Pharmacother. 2003, 57, 134-144. [CrossRef]

123. Köhrle, J.; Jakob, F.; Contempré, B.; Dumont, J.E. Selenium, the thyroid and the endocrine system. Endocr. Rev. 2005, 26, 944-948. [CrossRef] [PubMed]

124. McKenzie, R.C.; Arthur, J.R.; Beckett, G.J. Selenium and the regulation of cell signaling, growth, and survival: Molecular and mechanistic aspects. Antioxid. Redox Signal. 2002, 4, 339-351. [CrossRef] [PubMed]

125. Ponce, M.; Giraldez, I.; Calero, S.; Ruiz-Azcona, P.; Morales, E.; Fernández-Díaz, C.; Hachero-Cruzado, I. Toxicity and biochemical transformation of selenium species in rotifer (Brachionus plicatilis) enrichments. Aquaculture 2018, 484, 105-111. [CrossRef]

126. Lin, Y.-H.; Shiau, S.-Y. Dietary selenium requirements of juvenile grouper, Epinephelus malabaricus. Aquaculture 2005, 250, 356-363. [CrossRef]

127. Hamre, K.; Mollan, T.A.; Sæle, Ø.; Erstad, B. Rotifers enriched with iodine and selenium increase survival in Atlantic cod (Gadus morhua) larvae. Aquaculture 2008, 284, 190-195. [CrossRef]

128. Zhou, X.; Wang, Y.; Gu, Q.; Li, W. Effects of different dietary selenium sources (selenium nanoparticle and selenomethionine) on growth performance, muscle composition and glutathione peroxidase enzyme activity of crucian carp (Carassius auratus gibelio). Aquaculture 2009, 291, 78-81. [CrossRef] 
129. Ibrahim, A.T. Toxicological impact of green synthesized silver nanoparticles and protective role of different selenium type on Oreochromis niloticus: Hematological and biochemical response. J. Trace Elem. Med. Biol. 2020, 61, 126507. [CrossRef]

130. Luo, H.; Wang, Q.; He, Z.; Wu, Y.; Long, A.; Yang, Y. Protection of dietary selenium-enriched seaweed Gracilaria lemaneiformis against cadmium toxicity to abalone Haliotis discus hannai. Ecotoxicol. Environ. Saf. 2019, 171, 398-405. [CrossRef]

131. NRC. Nutrient Requirements of Fish and Shrimp; The National Academies Press: Washington, DC, USA, 2011.

132. Kim, H.-J.; Nakamura, K.; Hagiwara, A. Dietary effect of selenium-fortified Chlorella vulgaris on reproduction of Brachionus plicatilis species complex (Rotifera: Monogononta). Int. Rev. Hydrobiol. 2014, 99, 161-165. [CrossRef]

133. Ribeiro, A.R.; Ribeiro, L.; Sæle, Ø.; Hamre, K.; Dinis, M.T.; Moren, M. Selenium supplementation changes glutathione peroxidase activity and thyroid hormone production in Senegalese sole (Solea senegalensis) larvae. Aquac. Nutr. 2012, 18, 559-567. [CrossRef]

134. Penglase, S.; Hamre, K.; Sweetman, J.W.; Nordgreen, A. A new method to increase and maintain the concentration of selenium in rotifers (Brachionus spp.). Aquaculture 2011, 315, 144-153. [CrossRef]

135. Ribeiro, A.R.; Ribeiro, L.; Dinis, M.T.; Moren, M. Protocol to enrich rotifers (Brachionus plicatilis) with iodine and selenium. Aquac. Res. 2011, 42, 1737-1740. [CrossRef]

136. Suhajda, Á.; Hegóczki, J.; Janzsó, B.; Pais, I.; Vereczkey, G. Preparation of selenium yeasts I. Preparation of selenium-enriched Saccharomyces cerevisiae. J. Trace Elem. Med. Biol. 2000, 14, 43-47. [CrossRef]

137. Ursini, F.; Heim, S.; Kiess, M.; Maiorino, M.; Roveri, A.; Wissing, J.; Flohé, L. Dual function of the selenoprotein PHGPx during sperm maturation. Science 1999, 285, 1393-1396. [CrossRef] [PubMed]

138. Skalickova, S.; Milosavljevic, V.; Cihalova, K.; Horky, P.; Richtera, L.; Adam, V. Selenium nanoparticles as a nutritional supplement. Nutrition 2017, 33, 83-90. [CrossRef]

139. Wang, H.; Zhang, J.; Yu, H. Elemental selenium at nano size possesses lower toxicity without compromising the fundamental effect on selenoenzymes: Comparison with selenomethionine in mice. Free Radic. Biol. Med. 2007, 42, 1524-1533. [CrossRef]

140. Shoeibi, S.; Mashreghi, M. Biosynthesis of selenium nanoparticles using Enterococcus faecalis and evaluation of their antibacterial activities. J. Trace Elem. Med. Biol. 2017, 39, 135-139. [CrossRef]

141. Zhang, W.; Chen, Z.; Liu, H.; Zhang, L.; Gao, P.; Li, D. Biosynthesis and structural characteristics of selenium nanoparticles by Pseudomonas alcaliphila. Colloids Surf. Biointerfaces 2011, 88, 196-201. [CrossRef]

142. Forootanfar, H.; Adeli-Sardou, M.; Nikkhoo, M.; Mehrabani, M.; Amir-Heidari, B.; Shahverdi, A.R.; Shakibaie, M. Antioxidant and cytotoxic effect of biologically synthesized selenium nanoparticles in comparison to selenium dioxide. J. Trace Elem. Med. Biol. 2014, 28, 75-79. [CrossRef]

143. Srivastava, N.; Mukhopadhyay, M. Biosynthesis and structural characterization of selenium nanoparticles mediated by Zooglea ramigera. Powder Technol. 2013, 244, 26-29. [CrossRef]

144. Hamza, F.; Vaidya, A.; Apte, M.; Kumar, A.R.; Zinjarde, S. Selenium nanoparticle-enriched biomass of Yarrowia lipolytica enhances growth and survival of Artemia salina. Enzym. Microb. Technol. 2017, 106, 48-54. [CrossRef] [PubMed]

145. Shi, M.; Zhang, C.; Xia, I.F.; Cheung, S.T.; Wong, K.S.; Wong, K.-H.; Au, D.W.T.; Hinton, D.E.; Kwok, K.W.H. Maternal dietary exposure to selenium nanoparticle led to malformation in offspring. Ecotoxicol. Environ. Saf. 2018, 156, 34-40. [CrossRef] [PubMed]

146. Kim, H.-J.; Sakakura, Y.; Maruyama, I.; Nakamura, T.; Takiyama, K.; Fujiki, H.; Hagiwara, A. Feeding effect of selenium enriched rotifers on larval growth and development in red sea bream Pagrus major. Aquaculture 2014, 432, 273-277. [CrossRef]

147. Moren, M.; Opstad, I.; van der Meeren, T.; Hamre, K. Iodine enrichment of Artemia and enhanced levels of iodine in Atlantic halibut larvae (Hippoglossus hippoglossus L.) fed the enriched Artemia. Aquac. Nutr. 2006, 12, 97-102. [CrossRef]

148. Solbakken, J.S.; Berntessen, M.H.; Norberg, B.; Pittman, K.; Hamre, K. Different iodine and thyroid hormone levels between Atlantic halibut larvae fed wild zooplankton or Artemia from first exogenous feeding until post metamorphosis. J. Fish. Biol. 2002, 61, 1345-1362. [CrossRef]

149. Srivastava, A.; Hamre, K.; Stoss, J.; Nordgreen, A. A study on enrichment of the rotifer Brachionus "Cayman"with iodine from different sources. Aquaculture 2012, 334-337, 82-88. [CrossRef] 
150. Wang, J.; Wang, W.-X. Understanding the micro-elemental nutrition in the larval stage of marine fish: A multi-elemental stoichiometry approach. Aquaculture 2018, 488, 189-198. [CrossRef]

151. Nordgreen, A.; Penglase, S.; Hamre, K. Increasing the levels of the essential trace elements $\mathrm{Se}, \mathrm{Zn}, \mathrm{Cu}$ and $\mathrm{Mn}$ in rotifers (Brachionus plicatilis) used as live feed. Aquaculture 2013, 380-383, 120-129. [CrossRef]

152. Matsumoto, S.; Satoh, S.; Kotani, T.; Fushimi, H. Examination of a practical method for zinc enrichment of euryhaline rotifers (Brachionus plicatilis). Aquaculture 2009, 286, 113-120. [CrossRef]

153. Nguyen, V.T.; Satoh, S.; Haga, Y.; Fushimi, H.; Kotani, T. Effect of zinc and manganese supplementation in Artemia on growth and vertebral deformity in red sea bream (Pagrus major) larvae. Aquaculture 2008, 285, 184-192. [CrossRef]

154. Sun, S.; Chen, L.; Ge, X.; Qin, J.; Jiang, Z.; Li, E.-C. Effect of copper-enriched Artemia on growth, body composition, antioxidant enzyme activities, and osmotic stress tolerance of Chinese Mitten Crab Eriocheir sinensis larvae. J. Shellfish Res. 2013, 32, 759-766. [CrossRef]

155. Hamdan, R.; Othman, A.; Kari, F. Climate change effects on aquaculture production performance in Malaysia: An environmental performance analysis. Int. J. Bus. Soc. 2015, 16, 364-385. [CrossRef]

156. Allison, E.H.; Perry, A.L.; Badjeck, M.; Adger, W.N.; Brown, K.; Conway, D.; Halls, A.S.; Pilling, G.M.; Reynolds, J.D.; Andrew, N.L.; et al. Vulnerability of national economies to the impacts of climate change on fisheries. Fish Fish. 2009, 10, 173-196. [CrossRef]

157. Chen, H.; Liu, S.; Xu, X.-R.; Liu, S.-S.; Zhou, G.-J.; Sun, K.-F.; Zhao, J.-L.; Ying, G.-G. Antibiotics in typical marine aquaculture farms surrounding Hailing Island, South China: Occurrence, bioaccumulation and human dietary exposure. Mar. Pollut. Bull. 2015, 90, 181-187. [CrossRef]

158. Defoirdt, T.; Sorgeloos, P.; Bossier, P. Alternatives to antibiotics for the control of bacterial disease in aquaculture. Curr. Opin. Microbiol. 2011, 14, 251-258. [CrossRef]

159. Sharma, S.K.; Shankar, K.M.; Sathyanarayana, M.L.; Patil, R.R.; Swamy, H.N.; Rao, S. Development of biofilm of Vibrio alginolyticus for oral immunostimulation of shrimp. Aquac. Int. 2011, 19, 421-430. [CrossRef]

160. Santos, L.; Ramos, F. Antimicrobial resistance in aquaculture: Current knowledge and alternatives to tackle the problem. Int. J. Antimicrob. Agents 2018, 52, 135-143. [CrossRef]

161. Hoseinifar, S.H.; Sun, Y.Z.; Wang, A.; Zhou, Z. Probiotics as means of diseases control in aquaculture, a review of current knowledge and future perspectives. Front. Microbiol. 2018, 9, 2429. [CrossRef]

162. Gismondo, M.R.; Drago, L.; Lombardi, A. Review of probiotics available to modify gastrointestinal flora. Int. J. Antimicrob. Agents 1999, 12, 287-292. [CrossRef]

163. Fuller, R. Probiotics in man and animals. J. Appl. Bacteriol. 1989, 66, 365-378.

164. FAO/WHO. Guidelines for the Evaluation of Probiotics in Food; Food and Agriculture Organization \& World Health Organization: London, ON, Canada, 2002.

165. Sun, Y.-Z.; Yang, H.-L.; Huang, K.-P.; Ye, J.-D.; Zhang, C.-X. Application of autochthonous Bacillus bioencapsulated in copepod to grouper Epinephelus coioides larvae. Aquaculture 2013, 392-395, 44-50. [CrossRef]

166. Skjermo, J.; Bakke, I.; Dahle, S.W.; Vadstein, O. Probiotic strains introduced through live feed and rearing water have low colonizing success in developing Atlantic cod larvae. Aquaculture 2015, 438, 17-23. [CrossRef]

167. Gomez-Gil, B.; Roque, A.; Turnbull, J.F. The use and selection of probiotic bacteria for use in the culture of larval aquatic organisms. Aquaculture 2000, 191, 259-270. [CrossRef]

168. Douillet, P.A. Bacterial additives that consistently enhance rotifer growth under synxenic culture conditions: 1. Evaluation of commercial products and pure isolates. Aquaculture 2000, 182, 249-260. [CrossRef]

169. Douillet, P.A. Bacterial additives that consistently enhance rotifer growth under synxenic culture conditions: 2. Use of single and multiple bacterial probiotics. Aquaculture 2000, 182, 241-248. [CrossRef]

170. Le, D.V.; Nguyen, P.N.; Dierckens, K.; Nguyen, D.V.; De Schryver, P.; Hagiwara, A.; Bossier, P. Growth performance of the very small rotifer Proales similis is more dependent on proliferating bacterial community than the bigger rotifer Brachionus rotundiformis. Aquaculture 2017, 476, 185-193. [CrossRef]

171. Planas, M.; Vázquez, J.A.; Marqués, J.; Pérez-Lomba, R.; González, M.P.; Murado, M. Enhancement of rotifer (Brachionus plicatilis) growth by using terrestrial lactic acid bacteria. Aquaculture 2004, 240, 313-329. [CrossRef]

172. Pintado, J.; Pérez-Lorenzo, M.; Luna-González, A.; Sotelo, C.G.; Prol, M.J.; Planas, M. Monitoring of the bioencapsulation of a probiotics Phaeobacter strain in the rotifers Brachionus plizatilis using denaturing gradient gel electrophoresis. Aquaculture 2010, 302, 182-194. [CrossRef] 
173. Tinh, N.T.; Phuoc, N.N.; Dierckens, K.; Sorgeloos, P.; Bossier, P. Gnotobiotically grown rotifer Brachionus plicatilis sensu strictu as a tool for evaluation of microbial functions and nutritional value of different food types. Aquaculture 2006, 253, 421-432. [CrossRef]

174. Samat, N.A.; Yusoff, F.M.; Chong, C.M.; Karim, M. Enrichment of freshwater zooplankton Moina micrura with probiotics isolated from microalgae. J. Environ. Biol. 2020, 41, 1215-1223. [CrossRef]

175. Talpur, A.D.; Memon, A.J.; Khan, M.I.; Ikhwanuddin, M.; Danish Daniel, M.M.; Abol-Munaf, A.B. Effects of Lactobacillus probiotics on the enhancement of larval survival of Portunus pelagicus (Linnaeus, 175) fed via bioencapsulated in live feed. World J. Fish. Mar. Sci. 2012, 4, 42-49. [CrossRef]

176. Talpur, A.D.; Menon, A.J.; Khan, M.I.; Ikhwanuddin, M.; Danish Daniel, M.M.; Abol-Munafi, A.B. Supplementation of indigenous Lactobacillus bacteria in live prey and as water additive to larviculture of Portunus pelagicus (Linnaeus, 1758). Adv. J. Food Sci. Technol. 2011, 3, 390-398.

177. Verschuere, L.; Rombaut, G.; Sorgeloos, P.; Verstraete, W. Probiotic bacteria as biological control agent in aquaculture. Microbiol. Mol. Biol. Rev. 2000, 64, 655-671. [CrossRef] [PubMed]

178. Gatesoupe, F.J. The effect of three strains of lactic bacteria on the production rate of rotifers, Brachionus plicatilis, and their dietary value for larval turbot, Scophthalmus maximus. Aquaculture 1991, 96, 335-342. [CrossRef]

179. Aragón-Rojas, S.; Quintanilla-Carvajal, M.X.; Hernández-Sánchez, H. Multifunctional role of the whey culture medium in the spray drying microencapsulation of lactic acid bacteria. Food Technol. Biotechnol. 2018, 58, 381-397. [CrossRef]

180. Gatesoupe, F.J. Lactic acid bacteria increase the resistance of turbot larvae, Scophthalmus maximus, against pathogenic vibrio. Aquat. Living Resour. 1994, 7, 277-282. [CrossRef]

181. Patra, S.K.; Mohamed, K.S. Enrichment of Artemia nauplii with the probiotic yeast Saccharomyces boulardii and its resistance against a pathogenic Vibrio. Aquac. Int. 2003, 11, 505-514. [CrossRef]

182. Seenivasan, C.; Saravana Bhavan, P.; Radhakrishnan, S.; Shanthi, R. Enrichment of Artemia nauplii with Lactobacillus sporogenes for enhancing the survival, growth and levels of biochemical constituents in the post larvae of the freshwater prawn Macrobrachium rosenbergii. Turk. J. Fish. Aquat. Sci. 2012, 12, 23-31. [CrossRef]

183. Zakaria, Z.H.; Yaminudin, N.J.M.; Yasin, I.S.M.; Ikhsan, N.F.M.; Karim, M.M.A. Evaluation of Enterobacter sp. strain G87 as potential probiont against Vibrio harveyi infection in Artemia nauplii and Asian seabass (Lates calcarifer) larvae. Pertanika J. Trop. Agric. Sc. 2019, 42, 1251-1262.

184. Nimrat, S.; Suksawat, S.; Boonthai, T.; Vuthiphandchai, V. Potential Bacillus probiotics enhance bacterial numbers, water quality and growth during early development of white shrimp (Litopenaeus vannamei). Vet. Microbiol. 2012, 159, 443-450. [CrossRef]

185. Ziaei-Nejad, S.; Rezaei, M.H.; Takami, G.A.; Lovett, D.L.; Mirvaghefi, A.-R.; Shakouri, M. The effect of Bacillus spp. bacteria used as probiotics on digestive enzyme activity, survival and growth in the Indian white shrimp Fenneropenaeus indicus. Aquaculture 2006, 252, 516-524. [CrossRef]

186. Azimirad, M.; Meshkini, S.; Ahmadifard, N.; Hoseinifar, S.H. The effects of feeding with synbiotic (Pediococcus acidilactici and fructooligosaccharide) enriched adult Artemia on skin mucus immune responses, stress resistance, intestinal microbiota and performance of angelfish (Pterophyllum scalare). Fish. Shellfish Immunol. 2016, 54, 516-522. [CrossRef] [PubMed]

187. Rani, A.M.; Reddy, A.K.; Sahu, N.P. Growth enhancement and survival of Macrobrachium rosenbergii larvae fed Artemia nauplii enriched with cod liver oil and/or Lactobacillus. Isr. J. Aquac. 2006, 58, 183-190.

188. Lobo, C.; Martín, M.V.; Moreno-Ventas, X.; Tapia-Paniagua, S.T.; Rodríguez, C.; Moriñigo, M.A.; García de la Banda, I. Shewanella putrefaciens Pdp11 probiotic supplementation as enhancer of Artemia n-3 HUFA contents and growth performance in Senegalese sole larviculture. Aquac. Nutr. 2018, 24, 548-561. [CrossRef]

189. Semova, I.; Carten, J.D.; Stombaugh, J.; Mackey, L.C.; Knight, R.; Farber, S.A.; Rawls, J.F. Microbiota regulate intestinal absorption and metabolism of fatty acids in the zebrafish. Cell Host Microbe 2012, 12, 277-288. [CrossRef]

190. Rasmussen, B.B.; Kalatzis, P.G.; Middelboe, M.; Gram, L. Combining probiotic Phaeobacter inhibens DSM17395 and broad-host-range vibriophage KVP40 against fish pathogenic vibrios. Aquaculture 2019, 513, 734415. [CrossRef]

191. Hai, N.V. The use of probiotics in aquaculture. J. Appl. Microbiol. 2015, 119, 917-935. [CrossRef]

192. Gatesoupe, F.J. Updating the importance of lactic acid bacteria in fish farming: Natural occurrence and probiotic treatments. J. Mol. Microbiol. Biotechnol. 2008, 14, 107-114. [CrossRef] 
193. Makridis, P.; Fjellheim, A.J.; Skjermo, J.; Vadstein, O. Colonization of the gut in first feeding turbot by bacterial strains added to the water or bioencapsulated in rotifers. Aquac. Int. 2000, 8, 367-380. [CrossRef]

194. Olafsen, J.A. Interactions between fish larvae and bacteria in marine aquaculture. Aquaculture 2001, 200, 223-247. [CrossRef]

195. Nimrat, S.; Boonthai, T.; Vuthiphandchai, V. Effects of probiotic forms, compositions of and mode of probiotic administration on rearing of Pacific white shrimp (Litopenaeus vannamei) larvae and postlarvae. Anim. Feed Sci. Technol. 2011, 169, 244-258. [CrossRef]

196. Giarma, E.; Amanetidou, E.; Toufexi, A.; Touraki, M. Defense systems in developing Artemia franciscana nauplii and their modulation by probiotic bacteria offer protection against a Vibrio anguillarum challenge. Fish. Shellfish Immunol. 2017, 66, 163-172. [CrossRef] [PubMed]

197. Quiroz-Guzmán, E.; Vázquez-Juárez, R.; Luna-González, A.; Balcázar, J.L.; Barajas-Sandoval, D.R.; Martínez-Díaz, S.F. Administration of probiotics improves the brine shrimp production and prevents detrimental effects of pathogenic Vibrio species. Mar. Biotechnol. 2018, 20, 512-519. [CrossRef]

198. Vázquez-Silva, G.; Ramírez-Saad, H.C.; Aguirre-Garrido, J.F.; Mayorga-Reyes, L.; Azaola-Espinosa, A.; Morales-Jiménez, J. Effect of bacterial probiotics bio-encapsulated into Artemia franciscana on weight and length of the shortfin silverside (Chirostoma humboldtianum), and PCR-DGGE characterization of its intestinal bacterial community. Lat. Am. J. Aquat. Res. 2017, 45, 1031-1043. [CrossRef]

199. Kagali, R.N.; Kim, H.-J.; Koga, T.; Sakakura, Y.; Hagiwara, A. Effect of two commercial probiotic products on population growth of rotifer Brachionus rotundiformis Tschugunoff. Hydrobiologia 2019, 844, 173-182. [CrossRef]

200. Contreras-Tapia, R.A.; Castellanos-Páez, M.E.; Nandini, S.; Benítez-Díaz-Mirón, M.I.; Garza-Mouriño, G. Enhancing rotifer Brachionus calyciflorus population growth with commercial probiotics. Aquac. Res. 2020, 51, 2102-2111. [CrossRef]

201. Thammasorn, T.; Somchai, P.; Laosutthipong, C.; Jitrakorn, S.; Wongtripop, S.; Thitamadee, S.; Withyachumnarnkul, B.; Saksmerprome, V. Therapeutic effect of Artemia enriched with Escherichia coli expressing double-stranded RNA in the black tiger shrimp Penaeus monodon. Antiviral Res. 2013, 100, $202-206$. [CrossRef]

202. Venkat, H.K.; Sahu, N.P.; Jain, K.K. Effect of feeding Lactobacillus-based probiotics on the gut microflora, growth and survival of postlarvae of Macrobrachium rosenbergii (de Man). Aquac. Res. 2004, 35, 501-507. [CrossRef]

203. Vaghe, R.G.; Masouleh, A.R.S.; Alipour, A.R.; Yeganeh, H. Effects of Artemia nauplii enrichment with a bacterial species (Weissiella koreensis) on growth performance and survival rate of stellate sturgeon larvae (Acipenser stellatus). J. Surv. Fish. Sci. 2019, 5, 1-10. [CrossRef]

Publisher's Note: MDPI stays neutral with regard to jurisdictional claims in published maps and institutional affiliations.

(C) 2020 by the authors. Licensee MDPI, Basel, Switzerland. This article is an open access article distributed under the terms and conditions of the Creative Commons Attribution (CC BY) license (http://creativecommons.org/licenses/by/4.0/). 